\title{
Corruption, Seigniorage and Growth: Theory and Evidence
}

\author{
KEITH BLACKBURN \\ KYRIAKOS C. NEANIDIS \\ M. EMRANUL HAQUE
}

\begin{abstract}
CESIFO WORKING PAPER NO. 2354
CATEGORY 5: Fiscal POLICY, MACROECONOMICS AND GROWTH JULY 2008
\end{abstract}

\footnotetext{
An electronic version of the paper may be downloaded

- from the SSRN website: www.SSRN.com

- from the RePEc website: - from the CESifo website: 


\title{
Corruption, Seigniorage and Growth: Theory and Evidence
}

\begin{abstract}
This paper presents an analysis of the effect of bureaucratic corruption on economic growth through a public finance transmission channel. At the theoretical level, we develop a simple dynamic general equilibrium model in which financial intermediaries make portfolio decisions on behalf of agents, and bureaucrats collect tax revenues on behalf of the government. Corruption takes the form of the embezzlement of public funds, the effect of which is to increase the government's reliance on seigniorage finance. This leads to an increase in inflation which, in turn, reduces capital accumulation and growth. At the empirical level, we use data on 82 countries over a 20-year period to test the predictions of our model. Taking proper account of the government's budget constraint, we find strong evidence to support these predictions under different estimation strategies. Our results are robust to a wide range of sensitivity tests.
\end{abstract}

JEL Code: E6, H6, O16, O17, O42.

Keywords: corruption, seigniorage, inflation, growth.

$\begin{array}{cc}\text { Keith Blackburn } & \text { Kyriakos C. Neanidis } \\ \text { Economics Department } & \text { Economics Department } \\ \text { University of Manchester } & \text { University of Manchester } \\ \text { Oxford Road } & \text { Oxford Road } \\ \text { Manchester M13 9PL } & \text { Manchester M13 9PL } \\ \text { United Kingdom } & \text { United Kingdom } \\ \text { keith.blackburn@manchester.ac.uk } & \text { kyriakos.neanidis@manchester.ac.uk } \\ \text { M. Emranul Haque } & \\ \text { Economics Department } \\ \text { University of Manchester } \\ \text { Oxford Road } \\ \text { Manchester M13 9PL } \\ \text { United Kingdom } \\ \text { emranul.haque@manchester.ac.uk }\end{array}$

We are grateful to Toke Aidt, Michael Funke, Arye Hillman, Pantelis Kammas, Martin Paldam, Heracles Polemarchakis, and other participants of the CESifo-Delphi 2008 conference on "Institutions" and of the Birmingham 2008 conference on "Property Rights and Economic Development", for helpful comments and suggestions. 


\section{Introduction}

The relationship between public sector corruption and economic growth has been the subject of intense research, particularly over the past 15 years. $^{1}$ This research has led to the broad consensus that corruption is a major obstacle to growth and prosperity, and poses a serious (if not the primary) threat to economic and social development. The ways in which corruption can manifest and impact on the economy are many and varied, and it is important to understand the range and diversity of the mechanisms involved. In this paper we present a theoretical and empirical analysis of a mechanism that relates to public finance considerations.

The general negative relationship between corruption and growth has been identified in numerous empirical studies using various techniques and various data sets (e.g., Gyimah-Brempong 2003; Keefer and Knack 1997; Knack and Keefer 1995; Li et al. 2000; Mauro 1995; and Sachs and Warner 1997). ${ }^{2}$ These and other investigations (including theoretical work) also provide insight into the many channels through which corruption might take effect. A non-exhaustive list of these is the following: corruption may cause a misallocation of talent and skills away from productive (entrepreneurial) activities towards non-productive (rent-seeking) activities (e.g., Acemoglu 1995; Ehrlich and Lui 1999; Murphy et al. 1991); corruption may undermine the protection of property rights, create obstacles to doing business and impede innovation and technological transfer (e.g., Hall and Jones 1999; North 1990; World Bank 2002); corruption may cause firms to expand less rapidly, to adopt inefficient technologies and to shift their operations to the informal sector (e.g., Svensson 2005; Sarte 2000); corruption may limit the extent of a country's trade openness and reduce inflows of foreign investment (e.g., Pellegrini and Gerlagh 2004; Wei 2000); corruption may lead to costly concealment and detection of illegal income, resulting in a deadweight loss of resources (e.g., Blackburn et al. 2006; Blackburn and Forgues-Puccio 2007); corruption may compromise human development through a deterioriation in the scale and quality of public health and education programmes (e.g., Azfar 2001; Blackburn and Sarmah 2008; Gupta et al. 2000; Reinikka and Svensson 2005); and corruption may cause a general misallocation of public expendi-

\footnotetext{
${ }^{1}$ The most popular definition of public sector corruption is the abuse of public office for personal gain. For some excellent surveys of the corruption literature, see Aidt (2003), Bardhan (1997) and Jain (2001).

${ }^{2}$ By contrast, there is very little evidence to support the so-called "speed money" hypothesis, according to which corruption can be beneficial to growth by helping to circumvent cumbersome regulations (red tape) in the bureaucratic process (e.g., Huntington 1968; Leff 1964; Lui 1985).
} 
tures as certain areas of spending (e.g., military spending) are targeted more for their capacity to generate bribes than their potential to improve living standards (e.g., Gupta et al. 2001; Mauro 1998; Tanzi and Davoodi 1997). ${ }^{3}$

In terms of public finances, corruption may impact independently on both the expenditure and revenue sides of the government's budget: for any given state of the latter, corruption can distort the composition of expenditures in ways described above; for any given state of the former, corruption can alter the manner by which revenues must be generated, as suggested by other empirical evidence. Thus Ghura (1998), Imam and Jacobs (2007) and Tanzi and Davoodi $(1997,2000)$ conclude that corruption reduces total tax revenues by reducing the revenues from almost all taxable sources (including incomes, profits, property, capital gains and goods and services). The implication is that, ceteris paribus, other means of raising income must be sought, and one of the most tempting of these is seigniorage. Significantly, it has been found that inflation (a likely consequence of seigniorage) is positively related to the incidence of corruption (e.g., Al-Marhubi 2000), whilst seigniorage, itself, has a negative effect on growth (e.g., Adam and Bevan 2005; Bose et al. 2007). It is these observations that provide the motivation for this paper which seeks to analyse in detail (both theoretically and empirically) the influence of corruption on the composition of government revenues and the implications of this for growth and development. ${ }^{4}$

Our theoretical analysis is based on a stochastic dynamic general equilibrium model in which growth occurs endogenously through capital accumulation that is governed by the portfolio allocation decisions of financial intermediaries on behalf of agents. Following Diamond and Dybvig (1983) and Espinosa-Vega and Yip (1999, 2000), we consider a scenario in which individuals are subject to random relocation shocks that create a trade-off between investing in a productive, but illiquid, asset (capital) and a nonproductive, but liquid, asset (money). Intermediaries, which receive deposits from individuals, optimise this trade-off by choosing a composition of portfolio that depends on the relative rates of return of the two assets. An increase in inflation, which reduces the return on money, causes a portfolio

\footnotetext{
${ }^{3}$ In addition to all this, there is good reason for believing that the relationship between corruption and growth is two-way causal (i.e., that corruption not only influences, but is also influenced by, the level of economic prosperity). The support for this is both empirical (e.g., Montinola and Jackman 1999; Paldam 2002; Treisman 2000) and theoretical (e.g., Blackburn et al. 2006; Blackburn and Forgues-Puccio 2007; Blackburn and Sarmah 2008).

${ }^{4}$ Since the government budget constraint implies a link between monetary and fiscal policies, corruption of the latter may have serious consequences for the conduct of the former. See Huang and Wei (2006) for a recent analysis of the role of corruption in monetary policy.
} 
re-allocation away from capital investment (loans to firms) towards greater cash holdings in order to guarantee adequate provision of liquidity services for those agents who are forced to relocate. Against this background, we study the effects of corruption on growth and development. We model corruption as the embezzlement of public funds by bureaucrats who are appointed by the government to collect tax revenues from firms for the purpose of financing productive public expenditures. This looting of public resources means that, for any given levels of taxes and expenditures (together with the absence of borrowing), the government must rely more on the revenue from printing money (i.e., seigniorage) in order to satisfy its budget constraint. The effect of this is to increase inflation with the consequences described above. Since capital investment is lower, so too is the accumulation of capital and so too is the rate of growth.

Our empirical analysis aims to test the main predictions of our model. We use a panel of 82 countries covering all stages of development over the period 1980-1999. Based on a consistent treatment of the revenue side of the government budget constraint, we obtain results that offer strong support for the above conclusions. These results are robust to a wide range of senstitivity tests, including the use of alternative regression specifications, estimation techniques, instrumentation strategies, sample coverages and measurement approaches.

The remainder of the paper is organised as follows. Section 2 presents the theoretical analysis, setting out and solving our model economy to establish the key implications. Section 3 contains the empirical analysis, describing our methodology and data, presenting our basic findings and reporting on the results of extensive robustness tests. Section 4 contains a few concluding remarks.

\section{Theory}

Our theoretical model describes an overlapping generations economy in which there is an infinite sequence of two-period-lived agents who make up a constant population of unit mass. Each generation of agents is divided at birth into a fraction, $\mu \in(0,1)$, of private citizens (or households) and a remaining fraction, $1-\mu$, of public officials (or bureaucrats). ${ }^{5}$ Households work

\footnotetext{
${ }^{5} \mathrm{We}$ assume that agents are differentiated at birth according to their abilities and skills. Households are individuals who lack the skills necessary to become bureaucrats. Bureaucrats are individuals who possess these skills and who are induced to take up public office by an allocation of talent condition established below. Thus, as in other analyses (e.g., Blackburn et al. 2006; Blackburn and Forgues-Puccio 2007; Sarte 2000), we abstract
} 
for firms in the production of output, whilst bureaucrats work for the government in the administration of public policy. All agents work only when young and consume only when old. Consumption is financed from savings with financial intermediaries that make optimal portfolio choices on behalf of agents by allocating their deposits between liquid and illiquid assets. This role of intermediaries is created by the existence of idiosyncratic relocation shocks which also motivate a demand for liquidity. The government makes expenditures on public goods and services using whatever public funds and other means of finance are available. Corruption may occur because of the opportunity for bureaucrats to further their own interests by appropriating public funds for themselves. For reasons given below, we assume that at least some fraction, $\eta \in(0,1)$, of bureaucrats will never exploit such an opportunity, whilst the remaining fraction, $1-\eta$, may do so. ${ }^{6}$ Firms, of which there is a unit mass, conduct all of their business in perfectly competitive product and factor markets. In more detail the economy is descibed as follows.

\subsection{Government}

We envisage the government as providing public goods and services which contribute to the efficiency of output production. The real value of expenditure on these items, $g_{t}$, is assumed to be a fixed proportion, $\theta \in(0,1)$, of output, $y_{t}$. The government also incurs expenditures on bureaucrats' salaries which are determined as follows. Any bureaucrat (whether corruptible or non-corruptible) can work for a firm to earn an income equal to the wage paid to households. Any bureaucrat who is willing to accept a salary less than this wage must be expecting to receive compensation through some form of malpractice and is therefore immediately identified as being corrupt. As in other analyses (e.g., Acemoglu and Verdier 1998; Blackburn et al. 2006;

from issues relating to occupational choice. In doing so, we are able to simplify matters by not having to consider possible changes in the size of the bureaucracy and possible changes in the level of corruption that may result from this. Of course, we do not mean to undermine the importance of corruption in determining occupational choice. As indicated by others, an economy may well suffer as a consequence of this, with a misallocation of talent between productive (entrepreneurial) activities and non-productive (rent-seeking) activities (e.g., Acemoglu 1995; Murphy et al. 1991).

${ }^{6}$ This distinction between corruptible and non-corruptible bureaucrats may reflect differences in proficiencies at being corrupt or differences in moral attitudes towards being corrupt (e.g., Acemoglou and Verdier 2000; Besley and McLaren 1993; Blackburn et al. 2006; Tirole 1996). The main purpose of this assumption is to allow us to determine the wages of bureaucrats in a relatively straightforward way that does not demand additional assumptions about how public sector pay is determined. In fact, all we need for this purpose is that there be at least one bureaucrat who is non-corruptible - all other bureaucrats may well be potential transgressors. 
Blackburn and Forgues-Puccio 2007), we assume that a bureaucrat who is discovered to be corrupt is subject to the maximum fine of having all of his income confiscated (i.e., he is dismissed without pay). Consequently, no corruptible bureaucrat would ever reveal himself in the way described above. As such, the government can minimise its labour costs, whilst ensuring complete bureaucratic participation, by setting the salaries of all bureaucrats equal to the wage paid by firms to households. ${ }^{7}$ Denoting the real value of this wage by $w_{t}$, it follows that the total real wage bill for the government is $(1-\mu) w_{t}$.

To finance its expenditures, the government levies a tax on firms' output at the fixed proportional rate $\tau \in(0,1)$ and prints money to the tune of $M_{t}-M_{t-1}$, where $M_{t}$ denotes nominal cash balances. Responsibility for the collection of tax revenues lies with bureaucrats, each of whom has jurisdiction over the same number, $\frac{1}{1-\mu}$, of firms. The total amount of tax revenue collected individually is therefore $\frac{\tau y_{t}}{1-\mu}$. Each non-corrupt bureaucrat, of whom there are $\eta(1-\mu)$, returns all of this revenue to the government, whilst each corrupt bureaucrat, of whom there are $(1-\eta)(1-\mu)$, appropriates all of it for himself. Thus the actual amount of tax revenue available to the government is $\eta \tau y_{t}$.

Given the above, we may derive an expression for the government's budget constraint. Letting $P_{t}$ denote the price level, we write this in real terms as

$$
\frac{M_{t}-M_{t-1}}{P_{t}}+\eta \tau y_{t}=g_{t}+(1-\mu) w_{t}
$$

where $\frac{M_{t}-M_{t-1}}{P_{t}}$ is understood to be the government's total real revenue from printing money, or seigniorage.

\subsection{Agents}

All agents have the same preferences. For those born at time $t$, lifetime utility, $U_{t}$, is given by

$$
U_{t}=-\frac{c_{t+1}^{-\sigma}}{\sigma}
$$

$(\sigma>0)$ where $c_{t+1}$ denotes (old-age) consumption. Each and every agent is also endowed with the same unit amount of labour when young which is supplied inelastically to a given occupation (private employment or public service) in return for the same labour income of $w_{t}$. For a household and a non-corrupt bureaucrat, this is the only source of earnings. For a corrupt

\footnotetext{
${ }^{7}$ This has the usual interpretation of an allocation of talent condition. The government cannot force any of the potential bureaucrats to actually take up public office, but it induces all of them to do so by paying what they would earn elsewhere.
} 
bureaucrat, there is also the tax revenue, $\frac{\tau y_{t}}{1-\mu}$, that he embezzles. We assume that such an individual enjoys immunity from any risk of detection or punishment. This assumption (used in other analyses) is intended primarily as a simplification, though it is probably near the mark for many developing countries, where the will and wherewithal to combat corruption are relatively weak, and where perpertrators of corrupt practices can ply their trade with a good deal of confidence of impunity. ${ }^{8}$ To provide further motivation, we note that, in general, there are a number of ways in which corrupt individuals may conceal their behaviour, such as hiding their illegal income, investing this income differently from legal income and altering their patterns of expenditure. For the purposes of the present analysis, we suppose that the objective can be achieved if all ill-gotten gains are consumed immediately or disposed of in some other secure and unproductive way, rather than being saved in the same manner as labour income (i.e., deposited with financial intermediaries); otherwise, an offender is exposed with certainty.

As in Espinosa-Vega and Yip (1999, 2000), we consider the following scenario for introducing uncertainty among the population. Each agent of each generation is allocated at birth to one of two symmetric locations where he remains for the first period of his life. Subsequently, at the beginning of his second period of life, the agent is randomly reassigned locations. We denote by $q \in(0,1)$ the probability that an agent is relocated, $1-q$ being the probability that he stays where he is. Individuals' uncertainty about their future whereabouts is important for determining the composition of savings. The only means of saving that exist are a liquid, but unproductive, asset money - and an illiquid, but productive, asset - capital. Of these, only the former can be transferred between locations because of its liquidity. As such, agents may desire to save in the form of cash (even when it is dominated in rate of return), since this is the only means of smoothing consumption in the face of relocation shocks. Under such circumstances, there is a positive demand for money. We study this in detail in our subsequent analysis.

\footnotetext{
${ }^{8}$ Even when governments strive to be vigilant, corruption may thrive for a number of reasons, such as the prohibitive costs of fighting it when resources are scarce, the inherent difficulties in detecting it when monitoring is imprecise and the innate problems in exposing it when monitoring is abused. The last of these possibilities (where those appointed as vigilance officers are themselves open to bribes) bears on the interesting and complex issue of corruption in hierarchies (e.g., Basu et al. 1992; Marjit and Shi 1998; Mishra 2002). From a normative perspective, it has been shown by Bose (2004) how imperfect vigilance, combined with direct penalties for bribe-taking, may lead to outcomes that are Pareto-inferior to those that would occur if no sanctions were applied at all.
} 


\subsection{Firms}

The representative firm combines $l_{t}$ units of labour with $k_{t}$ units of capital to produce $y_{t}$ units of output according to

$$
y_{t}=A l_{t}^{\alpha} k_{t}^{\beta} g_{t}^{1-\beta}
$$

$(A>0, \alpha, \beta \in(0,1))$. The firm hires labour at the competitively-determined real wage $w_{t}$ and rents capital at the competitively-determined real interest rate $r_{t}$. Given that output is taxed at the rate $\tau$, profit maximisation implies $w_{t}=(1-\tau) \alpha A l_{t}^{\alpha-1} k_{t}^{\beta} g_{t}^{1-\beta}$ and $r_{t}=(1-\tau) \beta A l_{t}^{\alpha} k_{t}^{\beta-1} g_{t}^{1-\beta}$. Observe that equilibrium in the labour market requires $l_{t}=\mu$, and recall from our earlier discussion that $g_{t}=\theta y_{t}$. It follows that the foregoing conditions may be written as

$$
\begin{gathered}
w_{t}=\frac{(1-\tau) \alpha a}{\mu} k_{t}, \\
r_{t}=r=(1-\tau) \beta a,
\end{gathered}
$$

where $a=\left(A \mu^{\alpha} \theta^{1-\beta}\right)^{\frac{1}{\beta}}$. Thus equilibrium wages are proportional to the capital stock, whilst the equilibrium interest rate is constant.

\subsection{Financial Intermediaries}

As in the analysis of Diamond and Dybvig (1983), we view financial intermediaries as cooperative institutions consisting of coalitions formed by the young members of the population. The liquidity preference shocks which feature in that analysis have their counterpart in the relocations shocks which figure in our own investigation. We assume that these shocks are identically and independently distributed across agents who prefer to save through intermediaries, rather than by themselves, because doing so allows them to exploit the law of large numbers in eliminating individual risk.

Each period, intermediaries receive deposits from young agents and make portfolio allocation decisions in the interest of their depositors. The portfolio consists of money and capital, each of which has benefits and costs: money provides liquidity insurance for agents who are relocated, but does not pay any rate of interest; capital provides a rate of return for agents who are not relocated, but is unavailable to those who move. Intermediaries seek to optimise this trade-off by choosing a portfolio allocation and a configuration of deposit returns that maximise the expected welfare of their clients, subject to a set of resource constraints. Let $\delta_{t} \in(0,1)$ denote the fraction of deposits invested in capital (i.e., lent to firms) so that $1-\delta_{t}$ is the remaining fraction 
which is held as money. Also, let $i_{t}$ and $I_{t}$ denote, respectively, the gross real rates of return paid to depositors who move and do not move location. Finally, define $\pi_{t}=\frac{P_{t}}{P_{t+1}}$, the gross rate of deflation, or the real return on money. Then the decision problem for an intermediary is to choose values of $\delta_{t}, i_{t}$ and $I_{t}$ so as to maximise

$$
V_{t}=-q \frac{\left(w_{t} i_{t}\right)^{-\sigma}}{\sigma}-(1-q) \frac{\left(w_{t} I_{t}\right)^{-\sigma}}{\sigma}
$$

subject to

$$
\begin{array}{r}
q i_{t}=\left(1-\delta_{t}\right) \pi_{t}, \\
(1-q) I_{t}=\delta_{t} r .
\end{array}
$$

The expression in (6) is the expected utility of an agent who deposits the full amount of his labour income, $w_{t}$, and who faces a probability, $q$, of being relocated (in which case he receives a return of $i_{t}$ ) and a probability, $1-q$, of staying where he is (in which case he receives a return of $I_{t}$ ). The expression in (7) is the constraint which ensures that an intermediary is able to make a total real repayment of $q w_{t} i_{t}$ to those depositors who move location, using its total real holdings of money, $\left(1-\delta_{t}\right) w_{t} \pi_{t}$. The expression in (8) is the constraint which ensures that an intermediary is able to make a total real repayment of $(1-q) w_{t} I_{t}$ to those depositors who stay where they are, using the total proceeds from its capital investment, $\delta_{t} w_{t} r$.

Solving the above problem yields

$$
\delta_{t}=\frac{\left(\frac{q}{1-q}\right)\left(\frac{\pi_{t}}{r}\right)^{\frac{\sigma}{1+\sigma}}}{1+\left(\frac{q}{1-q}\right)\left(\frac{\pi_{t}}{r}\right)^{\frac{\sigma}{1+\sigma}}} \equiv \Delta\left(\pi_{t}\right) .
$$

Evidently, $\Delta^{\prime}(\cdot)>0$ : an increase in the return on money induces intermediaries to allocate a larger fraction of deposits towards capital. This is because lower inflation makes it easier for intermediaries to provide adequate liquidity for those agents who are relocated. Since less money needs to be held, a greater proportion of deposits can be allocated towards productive capital. ${ }^{9}$

\subsection{Balanced Growth Equilibrium}

Our model economy displays a unique balanced growth equilibrium in which all real variables grow at the same constant rate. This growth rate, denoted

\footnotetext{
${ }^{9}$ This is the income effect of a change in inflation. There is also a substitution effect, whereby the increase in return on money relative to capital (as a result of lower inflation) induces a portfolio reallocation from the latter to the former. Under our assumption that $\sigma>0$, the income effect dominates the substitution effect.
} 
by $\gamma$, is determined from the capital market equilibrium condition which states that the total demand for capital by firms must equal the total supply of capital by financial intermediaries. The former is given by $k_{t+1}$, whilst the latter is given by $\delta_{t} w_{t}$ (which is the total amount of deposits from households and bureaucrats that intermediaries allocate towards capital investment). Thus $k_{t+1}=w_{t} \delta_{t}$. Using (4), we may re-write this expression as $\frac{k_{t+1}}{k_{t}}=$ $\frac{(1-\tau) \alpha a}{\mu} \delta_{t}$. Evidently, $\frac{k_{t+1}}{k_{t}}$ (the growth rate of capital) is constant if $\delta_{t}$ (the portfolio share of capital) is constant which, from (9), requires that $\pi_{t}$ (the rate of deflation) is constant. Equilibrium growth is therefore determined as

$$
\gamma=\frac{(1-\tau) \alpha a}{\mu} \Delta(\pi)
$$

Since $\Delta^{\prime}(\cdot)>0$, an increase in inflation (i.e., a decrease in $\pi$ ) produces a fall in growth because of the reduction in productive investment. ${ }^{10}$ The basic objective of our analysis is to show how this may arise as a result of corruption.

Let $m_{t} \equiv \frac{M_{t}}{P_{t}}$, denote the total real value of money balances. Since intermediaries hold a fraction, $1-\delta_{t}$, of their total real deposits, $w_{t}$, as cash, we deduce that $m_{t}=w_{t}\left(1-\delta_{t}\right)$. Equivalently, using (4) and (9),

$$
m_{t}=\frac{(1-\tau) \alpha a}{\mu}[1-\Delta(\pi)] k_{t} .
$$

For reasons discussed already, an increase in inflation leads to an increase in real money holdings as intermediaries strive to provide adequate liquidity services for those agents who move location. Clearly, the growth rate of real balances satisfies $\frac{m_{t+1}}{m_{t}}=\gamma$.

Given the above, we may proceed to determine the rate of inflation. This is dictated by the financing needs of the government in accordance with its budget constraint in (1). We convert this constraint into a more convenient form as follows. Since $m_{t+1}=\gamma m_{t}$, we are able to write $\frac{M_{t}-M_{t-1}}{P_{t}}=$ $(\gamma-\pi) m_{t-1}$. We also recall (4) again, together with our other previous observations that $y_{t}=a k_{t}$ and $g_{t}=\theta a k_{t}$. Using (11), it then follows that (1) may be re-written as

$$
(\gamma-\pi)\left[\frac{1-\Delta(\pi)}{\Delta(\pi)}\right]+\eta \tau a=\theta a+\frac{(1-\mu)(1-\tau) \alpha a}{\mu} .
$$

The first term on the left-hand-side of this expression is the government's revenue from seigniorage. It comprises the inflation tax rate, $\gamma-\pi$, and

\footnotetext{
${ }^{10}$ That output grows at the rate $\gamma$ as well is confirmed by setting $l_{t}=\mu$ and $g_{t}=\theta y_{t}$ in (3) to obtain $y_{t}=a k_{t}$.
} 
the (growth-adjusted) inflation tax base, $\frac{1-\Delta(\cdot)}{\Delta(\cdot)}\left(=\frac{m_{t-1}}{k_{t}}\right)$. Ceteris paribus, an increase in inflation increases this revenue both directly (by raising the revenue from any given level of tax base) and indirectly (by increasing the level of tax base, itself). Of course, a full account of inflationary finance needs to acknowledge the opposite effect of $\pi$ on $\gamma$. These variables are understood as being determined jointly from the simultaneous system described by (10) and (12). Thus we combine these relationships to arrive at the following final expression for the determination of inflation:

$$
\left[\frac{(1-\tau) \alpha a}{\mu} \Delta(\pi)-\pi\right]\left[\frac{1-\Delta(\pi)}{\Delta(\pi)}\right]=\theta a+\frac{(1-\mu)(1-\tau) \alpha a}{\mu}-\eta \tau a .
$$

We are now in a position to study the effect of corruption on inflationary finance. Consider, first, the right-hand-side of (13) which shows the primary deficit of the government. Evidently, this is decreasing in $\eta$, the fraction of bureaucrats who are non-corrupt. When no bureaucrat is corrupt $(\eta=1)$, the government obtains the maximum tax revenue collected by bureaucrats from firms. When some bureaucrats are corrupt $(\eta<1)$, part of this revenue goes missing and the more of it does so the greater is the number of these individuals. Now consider the left-hand-side of (13) which shows the government's revenue from seigniorage. Using the expression for $\Delta(\cdot)$, it is straightforward to show that this is a decreasing function of $\pi$. Thus the observation made above continues to be true - namely, that an increase in seigniorage revenues is associated with an increase in inflation. Collecting these results together, we arrive at the conclusion that $\pi$ and $\eta$ are positively related: inflation in a corrupt environment is greater than inflation in a non-corrupt environment.

Having established the above, it is a short step to realise the effect of corruption on growth. As we have seen in (10), growth is negatively related to inflation because of intermediaries' optimal portfolio allocation decisions: higher inflation induces lower capital investment as intermediaries seek to enhance their currency reserves. Since higher inflation is caused by corruption, then corruption is the source of lower growth.

\section{Evidence}

Our theoretical analysis yields predictions which, in principle, may be tested empirically. We seek to do this in the remainder of the paper. Our primary objective is to evaluate the extent to which corruption has an indirect adverse effect on growth through its distortion of government revenues in favour of seigniorage. 


\subsection{Estimation Strategy and Methodology}

Our empirical strategy is to predict growth using a consistent treatment of the government budget constraint, together with commonly-employed indicators of corruption. We concern ourselves not with the entire budget constraint, but rather with only its revenue components since it is these for which our theoretical analysis makes predictions, the general conjecture being that corruption alters the relative importance of alternative sources of finance. More specifically, our focus is on a coeffcient of interaction term between corruption and seigniorage which we incorporate into our growth regressions, taking proper account of the revenue side of the public sector accounts.

We begin by computing the budget shares of the different components of public finance - that is, the value of each component as a proportion of total revenues plus the budget deficit. In doing so, we take account of two considerations. First, as pointed out by others, since these financing variables are bound together in an indentity, one of them needs to be removed in order to avoid perfect multi-collinearity among the fiscal regressors in the estimated growth equation (e.g., Adam and Bevan 2005; Bose et al. 2007; Kneller et al. 1999). The coefficients on the remaining financing variables are then understood as measuring their effect on growth net of the effect of the excluded variable. Second, it is also necessary to control for the level effects of total revenue and the budget deficit on growth, independently of their composition effects. As elsewhere, we do this by taking the ratio of these variables to GDP (e.g., Devarajan et al. 1996). ${ }^{11}$

Given the above, our benchmark growth regression model is

$$
\begin{aligned}
g_{i t}=\alpha & +\sum_{l=1}^{m} \beta_{l} X_{l, i t}+\sum_{j=1}^{n} \gamma_{j} Z_{j, i t}+\zeta \frac{T R_{i t}+B D_{i t}}{G D P_{i t}} \\
& +\theta C_{i t}+\lambda C_{i t} S_{i t}+\mu_{i}+\nu_{t}+\varepsilon_{i t}
\end{aligned}
$$

where the notation is as follows: $i$ is the country index; $g_{i t}$ denotes the growth rate of per capita real GDP; $\left\{X_{l, i t}\right\}_{l=1}^{m}$ represents a set of non-fiscal conditioning variables that typically appear in growth regressions; $\left\{Z_{j, i t}\right\}_{j=1}^{n}$ represents the set of budget revenue variables, measured as fractions of total revenue plus grants, $T R_{i t}$, plus the budget deficit, $B D_{i t} ; C_{i t}$ denotes an index of corruption; $C_{i t} S_{i t}$ is the interaction term between corruption and seigniorage; $\mu_{i}$ and $\nu_{t}$ capture time-invariant country-specific effects and time-varying common effects, respectively; and $\varepsilon_{i t}$ is the error term.

The set $\left\{X_{l, i t}\right\}_{l=1}^{m}$ includes a baseline group of controls comprising the log of initial real GDP per capita, the ratio of investment to GDP and the

\footnotetext{
${ }^{11}$ As shown later, including these variables separately does not alter our results.
} 
rate of population growth. Added to these, the extended group of controls includes the log of initial primary school enrollment rates, the ratio of trade to GDP, the rate of inflation and a dummy variable for countries located in the tropical climate zone. ${ }^{12}$ The set $\left\{Z_{j}\right\}_{j=1}^{n}$ is defined initially to include seigniorage and debt, with other revenue components excluded for reasons given above. ${ }^{13}$ If these other sources of finance are labelled collectively by $Z_{0}$, then given the budget identity $\sum_{j=0}^{n} Z_{j}=1$, the coefficient $\gamma_{j}=\left(\delta_{j}-\delta_{o}\right)$ is understood to measure the marginal impact on growth of the included fiscal factor $Z_{j}$, net of the marginal impact of the excluded factor $Z_{0}$. The variables $T R_{i t}$ and $B D_{i t}$ are used to control for any level effect of revenue on growth, as alluded to earlier. The term $C_{i t} S_{i t}$ is the key element in our regression, being used to capture the idea that a higher incidence of corruption, by inducing a greater reliance on seigniorage, has an adverse effect on growth. We therefore interpret a negative value of $\lambda$ as evidence of corruption impeding growth through its influence on the composition of public finances. The terms $\mu_{i}$ and $\nu_{t}$ are incorporated in our benchmark panel specification as a means of allowing both fixed-country and time-specific effects to capture certain observed patterns in growth - in particular, the uneveness of growth across countries and the general slowdown of growth since the early 1980s. ${ }^{14}$

The panel estimations we use are based on techniques that address the potential endogeneity of the right-hand-side variables (in particular, the possibility that the fiscal and corruption variables may be influenced by growth). The first method is a standard two-stage least squares estimation (2SLS), where the instruments are either the initial or lagged values of the variables. ${ }^{15}$ The idea is that these values may plausibly be taken as exogenous to the subsequent five years of growth (the period of our averaging). The second method is the system-GMM estimation developed by Blundell and Bond (1998). This technique accounts for possible endogeneity by employing a rich set of endogenous instruments, treating the model as a system of equations in first-differences and in levels. The endogenous variables in the first-difference equations are instrumented with lags of their levels, whilst

\footnotetext{
${ }^{12}$ The inclusion of inflation as an explanatory variable in the growth regression is meant to capture any potential independent effect of inflation on growth beyond its possible effect through seigniorage.

${ }^{13}$ In our subsequent robustness analysis, we examine the implications of excluding each of the former variables, as well as using a more disaggregated measure of other revenues.

${ }^{14}$ In our instrumental variable regressions, we also include dummies that capture continent-specific effects. Although not reported, it turns out that, in general, all sets of dummies are strongly significant and pick up much of the growth differences across countries, regions, and time periods.

${ }^{15}$ Countries missing the very first observation of the respective period averaging are instrumented by their second observation, or are dropped if no early enough data exist.
} 
the endogenous variables in the level equations are instrumented with lags of their first differences. A difficulty associated with system-GMM relates to the choice of the number of lags of the endogenous and predetermined variables. To enhance the robustness of our results, we estimate our model with different sets of lags. We initially use an unrestricted number of lags, starting at a lag length of two, and thereafter reduce the length of the maximum lags to four and then three. This allows us to restrict the number of instruments to be less than the number of countries in the regression. ${ }^{16}$

In the system-GMM approach we check the validity of the instruments by applying two specification tests. The first is the Hansen (1982) J-test of over-identifying restrictions which we use to examine the exogeneity of the instruments. This test is consistent in the presence of both heteroscedasticity and autocorrelation of any pattern. ${ }^{17}$ The second is the Arellano and Bond (1991) test for serial correlation, the existence of which can cause a bias to both the estimated coefficients and standard errors. We apply this test to all of our instrumental variable regressions, checking for serial correlation of both first and second order. When the former is detected, we make the standard errors robust to serial correlation by clustering them by country. Additionally, in order to avoid dynamic panel bias, we instrument for regressors that are not strictly exogenous. These include investment in the baseline control set, and trade and inflation in the extended set. Finally, we note that, since the system-GMM strategy of first-differencing induces first-order serial correlation in the transformed errors, the appropriate check in this case relates only to the absence of second-order serial correlation.

\subsection{Data}

We use a panel of 82 countries (a list of which is given in the Appendix) for the period 1980-1999. The choice of period is restricted by data availability for corruption, credible measures of which did not exist prior to the early 1980s. We follow the standard approach of constructing 5-year period averages (1980-84 to 1995-99) so as to minimise business cycle effects. This implies a maximum sample size of 328 observations, though we end up working with an unbalanced panel of 254 observations because of missing data.

\footnotetext{
${ }^{16}$ As pointed out by Roodman (2004), an excessive number of instruments can result in an overfitting of the instrumented variables, thereby biasing the results towards those of the OLS.

${ }^{17}$ Failure of the null hypothesis suggests that the set of instruments is incomplete implying omitted variables bias.
} 
Table 1 presents some summary statistics of the data, as well as providing definitions and sources. A few further comments about particular variables are as follows. Following Fischer (1982) and Cukierman et al. (1992), seigniorage is defined to be the change in reserve money as a fraction of total revenue, grants and the budget deficit. Debt-financing is measured along the lines of Adam and Bevan (2005) and Bose et al. (2007) as the residual between the budget deficit and seigniorage. Our benchmark measure of corruption is given by the International Country Risk Guide (ICRG) index which we supplement later with three others - the Transparancy International (TI) index, the Dreher et al. (2007) (DKM) index and the Kaufmann et al. (2006) (KKM) index. Where appropriate, we re-scale the indices to make them comparable in the sense that a higher score on each of them corresponds to a higher level of corruption.

A first indication that our theoretical results may have empirical support is given in Figure 1 which displays cross-country scatterplots of the level of seigniorage against the four alternative corruption indices. Whilst the latter involve different period averages, all of the scatterplots show a broad positive relationship between seigniorage and corruption, with the correlation coefficient ranging between 0.35-0.41. Given this, we are encouraged to pursue a more formal analysis of the joint importance of these variables in determining growth.

\subsection{Baseline Results}

We begin our investigations by estimating equation (14) with fixed-effects, 2SLS and system-GMM using the set(s) of control variables described above. Our findings are presented in Table 2. Panel A reports the results of the regressions with the baseline set of controls, while Panel B reports the results with the extended set. Before discussing these results in detail, we note that our main theoretical conjecture is strongly supported in each case. The coefficient on the interaction term Seigniorage* $I C R G$ is negative and statistically significant in all regressions. Thus, seigniorage appears to have a stronger adverse growth effect in countries that are characterised by high levels of corruption.

The fixed-effects results in column (1) illustrate the typical findings of growth regressions concerning the set of non-fiscal controls: there is conditional income convergence, a positive influence of investment and a negative influence of population growth. As regards the effects of the fiscal variables, recall that we omit the category of total revenue and grants as a way of avoiding collinearity problems. This means that the estimated coefficient on each included source of finance is a measure of the marginal impact on 
growth of raising revenue from that source in order to offset a reduction in the excluded component. ${ }^{18}$ According to our results, the marginal impact of raising debt is significantly negative, whilst the marginal impact of raising seigniorage is not significantly different from zero. The implication is that the compositional trade-off between debt and total revenue is growth-inhibiting, whilst the compositional trade-off between seigniorage and total revenue is growth-neutral. As observed in other growth studies, we find that the level effect of total revenue (including grants) plus the budget deficit is negative (e.g., Bose et al. 2007; Kneller et al. 1999). ${ }^{19}$ Since we do not control for any category of public expenditure, this level effect can be interpreted to mean that an increase in the financing of total expenditures has an adverse effect on growth. It is worth noting that our results remain unchanged when we do control for different types of expenditure and allow ourselves to capture the separate effects of these (for example, the effects of productive versus residual expenditures). ${ }^{20}$ Turning to corruption, we find that this has no statistically significant direct effect on growth. This is not an usual result: as first pointed out by Mauro (1995), corruption affects growth only indirectly through its effect on other factors, such as investment. The fact that we already include investment in our regression means that we control for this channel of influence. Similar observations are made by Pellegrini and Gerlagh (2004), whilst other authors have identified the context-specific nature of the effects of corruption. ${ }^{21}$ By contrast, the interaction term between corruption and seigniorage is seen to have a strongly significant negative impact on growth. This accords well with our main conjecture that corruption affects growth indirectly by tilting the composition of public finances towards greater seigniorage.

The 2SLS results in columns (2) and (3) provide further support for our

\footnotetext{
${ }^{18}$ As indicated earlier, our analysis of robustness reveals that the choice of which component to exclude is inconsequential for our results, having little bearing on the model's statistical properties. In addition, the coefficients on all components are fully recoverable by substitution between the different versions of the model.

${ }^{19}$ Once again, we draw attention to the distinction between the compositional and level effects on growth of the different categories of finance and the budget deficit. For further evidence of the latter, see Adam and Bevan (2005), Bose et al. (2007) and Miller and Russek (1997).

${ }^{20}$ Following Adam and Bevan (2005), we define productive expenditure as expenditure on health, education, infrastructure, public order, safety, and public administration, whilst residual expenditure refers to spending on economic services, recreation and culture, and other miscellaneous items. This classification also accords with Kneller et al. (1999).

${ }^{21}$ For example, Méndez and Sepúlveda (2006) conclude that the negative effect of corruption on growth is confined mainly to "free" countries, whilst Aidt et al. (2007) find that the effect is strong only in countries with a high quality of political institutions.
} 
main hypothesis. The potentially endogenous regressors that we instrument for (indicated by bold type) are investment, corruption and the fiscal variables in Panel A, augmented by trade and inflation in Panel B. Column (2) corresponds to the case in which we instrument with inital values, whilst column (3) represents the case in which we instrument with once-lagged values. Controlling for endogeneity improves the fit of the regression without dramatically altering any of the results (aside from debt-financing becoming insignificant). In all cases the coefficient on the corruption-seigniorage interaction term remains similar in magnitude and significance to what it was before. In all cases, as well, the Arellano and Bond (1991) specification test reveals the absence of both first- and second-order serial correlation in the error term (i.e., the test fails to reject the null hypothesis of neither type of serial correlation at the 5 percent level).

The system-GMM results in columns (4), (5) and (6) provide final evidence in favour of our model. The regression employed in column (4) involves all possible lags of the endogenous variables as instruments, starting from the second lag, whilst the regressions used in columns (5) and (6) restrict the maximum number of lags to 4 and 3 , respectively (so that the number of instruments diminish as one moves from left to right across the Table). The coefficient on the interaction term, whilst somewhat lower (in absolute value) than in the previous regressions, continues to be negative and significant irrespective of the number of instruments used. In addition, the validity of the instruments are confirmed by both the Hansen (1982) and Arellano and Bond (1991) specification tests (the former being unable to reject the null of instrument exogeneity at the 5 percent level, and the latter being unable to reject the null of no second-order serial correlation, also at the 5 percent level).

The final point to note from our baseline findings is that the coefficient on the interaction term is fairly stable across the different regressions (especially in panel $A$ ) and that its value implies a large quantitative effect of corruption on growth. To appreciate the size of this effect, consider a country that lies at the 75th percentile of our data on corruption and seigniorage. This country is predicted to grow by 1.57 percentage points slower than a country at the 50 th percentile, and by 2.15 percentage points slower than a country at the 25 th percentile. These orders of magnitude are clearly non-trivial. ${ }^{22}$

\footnotetext{
${ }^{22}$ The calculations are based on the average of the interaction terms $(-0.707)$ in Panel A. The 75th, 50th and 25th percentiles for the corruption index are 3.31, 2.67 and 1, respectively. The corresponding values for seigniorage are $0.095,0.035$ and 0.013 .
} 


\subsection{Robustness}

We examine the sensitivity of our baseline results by re-running the regressions under various modifications. These include the exclusion of alternative fiscal components, the removal of one country at a time from the sample, the use of alternative measures of corruption and seigniorage, and the modelling of non-linearities and convergence effects. As we shall see, our basic findings survive all of these robustness checks.

\subsubsection{Exclusion of Alternative Revenue Categories}

Our estimations have so far been based on the exclusion of total revenue and grants from the list of fiscal regressors. We now alter our choice of which financing category to leave out, the results from doing which are summarised in Table 3. Column (1) represents the case in which debt financing is excluded, whilst column (2) corresponds to the case in which seigniorage is omitted. As before, the estimated coefficient on each remaining fiscal variable gives the marginal impact on growth of increasing that variable in order to compensate for a reduction in the excluded component. For example, a compensated reduction of debt by an increase in either seigniorage or total revenue and grants is found to be growth-neutral at the 5 percent level. In terms of our main concern, the results provide confirmation of our previous findings. Indeed, the general conclusion to draw from this exercise is that the choice of which financing component to exclude has no bearing on the statistical properties of the model, nor on the coefficient estimates of the non-fiscal variables (including, importantly, the multiplicative interaction term).

As a further robustness check, we perform a similar exercise for the fixed effects and 2SLS regressions by disaggregating the category of total revenue and grants into three components - tax revenue, non-tax revenue and grant income. Thus we expand the total number of financing components from 3 to 5. Choosing grants as the excluded category (which has the fewest number of observations), we obtain similar results to those above. These are presented in columns (3), (4) and (5) of Table 3, where we focus on the interaction term to keep to the bare essentials. Again, we find that this term remains negative, significant and stable across all regressions.

\subsubsection{Testing for Outliers}

To check that our findings are not driven by outliers, we first re-run the benchmark regressions of columns (1), (2) and (3) in Table 2, dropping one country at a time. Table 4 reports the new coefficient estimates of the seignioragecorruption interaction term, together with the $t$-statistics and $p$-values for 
the minimum and maximum values of this estimate. The results indicate significant robustness to all specifications, delivering minimum $t$-statistics that are well above conventional significance levels. Given this, we conclude that our findings are not driven by outliers.

We next check again the specification of our model, focusing specifically on the joint variable of total revenue, grants and the budget deficit that we have been using to control for level effects. We examine whether the use of this variable has been biasing the results by splitting the variable into its two components. Our findings, reported in column (1) of Table 5, suggest that only the level effect of total revenue and grants is significant. Other than this, our previous results are unchanged.

Finally, we run a regression based on observations for which the absolute value of seigniorage does not exceed the absolute value of the budget deficit. The idea behind this is to consider only those countries in which seigniorage is used to part-finance budget deficits, excluding others where money is printed excessively in the sense of not being justified by budget requirements, but rather being due to other reasons. The results, shown in column (2) of Table 5 , remain the same as before.

\subsubsection{Alternative Measures of Corruption and Seigniorage}

In all of the preceding analysis we have adopted the ICRG index as our measure of corruption. This is not the only measure, however, and it is important to verify that our results can be established with the use of others. As mentioned earlier, we consider three alternatives which differ in terms of their coverage and construction. These are the Transparency International (TI) index, the Kaufmann et al. (2006) (KKM) index, and the Dreher et al. (2007) (DKM) index. Our initial preference for the ICRG index is due to its uninterupted annual coverage over a relatively long period (1984-1999), allowing us to use both initial and lagged values as instruments in our 5-year period averaging. By contrast, the TI and KKM indices give annual observations only after 1995 and 1996, respectively, making it impractical to apply the same instrumentation techniques. ${ }^{23}$ The most ideally suited alternative is the DKM index which extends the furthest backwards, reporting period averages from 1976-80 to 1991-97. In spite of their differences, however, all of these indices display high correlations - 0.90 (TI), 0.86 (KKM) and 0.74 (DKM) - with the ICRG index. This suggests that the choice of corruption measure ought not to have a substantial impact on our results, a presumption that is confirmed when we re-run the regressions under each alternative. We

\footnotetext{
${ }^{23}$ Whilst the TI index extends back to 1980 , the first two observations are period averages for 1980-85 and 1988-92.
} 
illustrate this in Table 5, column (3) of which is based on the fixed-effects regression using the TI index (implying a reduction in sample size by as much as one-third), whilst columns (4) and (5) involve the same regression but using the DKM index.

In similar vein, we also check the sensitivity of our results to alternative measures of seigniorage. These are the measures proposed by Walsh (1998), Honohan (1996) and de Haan et al. (1993) which we label, respectively, as Seigniorage $2_{t}$, Seigniorage $3_{t}$, and Seigniorage $4_{t}$, and which we calculate as follows:

$$
\begin{gathered}
\text { Seigniorage } 2_{t}=\frac{m_{t}}{T R_{t}+B D_{t}}-\frac{m_{t-1}}{T R_{t-1}+B D_{t-1}}+\frac{m_{t}}{T R_{t}+B D_{t}} \frac{\dot{m}_{t}}{1+\dot{m}_{t}} \\
\text { Seigniorage } 3_{t}=\frac{\dot{m}_{t} m_{t}}{T R_{t}+B D_{t}} \\
\text { Seigniorage }_{t}=\frac{\pi_{t}}{1-\pi_{t}} \frac{m_{t}}{T R_{t}+B D_{t}}
\end{gathered}
$$

where $m_{t}$ denotes reserve money ( $\dot{m}_{t}$ being its rate of growth), $\pi_{t}$ is the rate of inflation, and $T R_{t}$ and $B D_{t}$ are as defined earlier. The results obtained from re-running our 2SLS (with initial values as instruments) and systemGMM regressions are recorded in Table 6 . In all cases our previous findings are confirmed, with the corruption-seigniorage interaction term remaining negative, significant and of the same order of magnitude.

\subsubsection{Non-linear, Convergence, and Other Interaction Effects of Corruption and Seigniorage}

It has been suggested by some authors that the effect of corruption on growth exhibits diminishing returns (e.g., Méndez and Sepúlveda 2006) and that the growth effects of fiscal variables (including seigniorage) are also non-linear (e.g., Adam and Bevan 2005). One potential explanation for our negative interaction term could be that it is the result of a similar non-linearity which is not accounted for in our estimation procedure. For example, it is possible that this term is proxying for the squared levels of corruption and seigniorage, rather being an important explanatory variable in its own right. To check this, we modify our regression specification to allow for these squared effects, thereby enabling us to test whether the interaction term has an independent impact on growth in the presence of non-linearities. The results from doing this are given in columns (1) and (2) of Table 7, where it is seen that the interaction term remains negative and significant, whilst neither of the squared 
terms are significantly different from zero. Given this, we conclude that our findings are not driven by non-linear corruption and seigniorage effects. ${ }^{24}$

A related issue concerns the possibility of convergence effects induced by corruption and seigniorage. Recent empirical studies have shown that both corruption and seigniorage play a potentially important role in the convergence of income across countries (e.g., Bose et al. 2007; Keefer and Knack 1997). If either of these variables are strongly correlated with initial income, then our estimated interaction term could be picking up such a role. To avoid this, we re-run our regressions with seigniorage and corruption alternately interacting with log of initial income. Our results, reported in columns (3) and (4) of Table 7 , show that the seigniorage-corruption interaction term continues to be negative and significant at the 1 percent level. In addition, there is evidence of both a direct effect of corruption on growth and an indirect effect through income convergence (implying that corruption is particularly harmful in more developed countries). The growth effects of seigniorage, by contrast, do not appear to be widely different across different income levels.

A final set of checks that we undertake is motivated by the observation that the negative effect of corruption on growth is not always as strong as is often claimed, but rather appears to be context-specific. For example, there is evidence to suggest that the effect is most pronounced in countries with large government sectors (e.g., Mauro 1998), in countries located in Africa and Latin America (e.g., Gyimah-Brempong and Camacho 2007) and in countries with poorly-developed financial systems (e.g., Ahlin and Pang 2007). We therefore test the validity of our results when such considerations are taken into account. Our findings are summarised again in Table 7. Column (5) shows what happens when we re-run our baseline regression with the inclusion of an interaction term between corruption and financial development. Following Ahlin and Pang (2007), we measure the latter variable by the total amount of credit issued to private enterprises by deposit money banks and other financial institutions, normalised by GDP. We obtain similar results to those authors, with the new interaction term being positive and significant (albeit at the 10 percent level). This indicates a substitutability between the variables that make up this term: when corruption is high (financial development is low), the marginal impact from improving financial development (reducing corruption) is greater. As regards the interaction term between corruption and seigniorage, the estimated coefficient on this remains negative and significant at the 1 percent level. Column (6)

\footnotetext{
${ }^{24}$ Although we report regressions where each squared term is added in turn, the inclusion of both squared terms simultaneously does not alter our results. Similarly, our findings remain intact if we amend the regression further to include Inflation* $I C R G$ and its squared term to control for other non-linearities.
} 
reveals the effects of incorporating government consumption expenditure, together with its interaction with corruption, in our baseline specification. We observe, again, that the corruption-seigniorage interaction term continues to be negative and significant at the 1 percent level. By contrast, the additional interaction term is insignificant, a finding which is also obtained by Méndez and Sepúlveda (2006) and which counters the argument of Mauro (1998) that corruption is more detrimental when governments are larger. Finally, column (7) shows the implications of modifying our regression to include interaction terms between corruption and regional dummies. We find that the interaction involving Latin American countries is negative and significant, whilst the interaction involving African countries is insignificant. The first result is consistent with the conclusion of Gyimah-Brempong and Camacho (2007) that corruption is especially harmful to growth in Latin American economies, but the second result runs counter to the same authors' similar conclusion regarding African economies. Once again, the sign and significance of our corruption-seigniorage interaction term remain unchallenged.

\section{Concluding Remarks}

Our aim in this paper has been to study how bureaucratic corruption may impact on economic growth through its effect on public finances. The basic idea is that corruption alters the composition of government revenues, causing an increase in inflationary finance and, with this, a reduction in capital accumulation. This idea is formalised within a simple theoretical model and supported by strong empirical evidence.

The theoretical model describes an endogenously growing economy in which financial intermediaries make portfolio decisions on behalf of agents and bureaucrats collect tax revenues on behalf of the government. Intermediaries choose how much of their deposits to invest in capital and how much to hold as money, where the latter is motivated by the existence of idiosyncratic relocation shocks. Bureaucrats seek to enrich themselves by embezzling tax revenues, the effect of which is to increase the government's reliance on seigniorage as a means of financing its expenditures. A higher level of seigniorage implies a higher rate of inflation which induces a portfolio reallocation away from capital towards money. Growth is reduced as a result.

The supporting empirical evidence is obtained by applying standard regression techniques to trace the impact of corruption on growth when the share of seigniorage in total government revenue is a conditioning variable. Taking proper account of the government's budget constraint, our econometric analysis confirms the basic predictions of our model. Specifically, we find 
strong evidence of a negative interaction between corruption and seigniorage, as is consistent with the idea that corruption tends to aggravate the harmful effects of inflationary finance. Our results are robust to a wide range of sensitivity tests and efforts to control for simultaneity bias.

In summary, this paper highlights a potentially important channel through which corruption may adversely affect growth. This channel operates indirectly via the impact of corruption on the composition of public finances. 


\section{Appendix: Sample Countries}

Argentina, Austria, Bahamas, Bahrain, Belgium, Bolivia, Brazil, Bulgaria, Burkina Faso, Cameroon, Canada, Chile, Colombia, Congo Dem. Rep., Congo Rep., Costa Rica, Cote d'Ivoire, Cyprus, Czech Rep., Denmark, Dominican Rep., Egypt, El Salvador, Ethiopia, Finland, France, Gabon, Gambia, Germany, Greece, Guatemala, Guyana, Haiti, Hungary, Iceland, India, Indonesia, Iran, Ireland, Israel, Italy, Jamaica, Japan, Korea Rep., Kuwait, Luxembourg, Madagascar, Malaysia, Mali, Malta, Mongolia, Namibia, Netherlands, Nicaragua, Norway, Panama, Paraguay, Peru, Poland, Portugal, Romania, Russia, Senegal, Singapore, Slovak Rep., South Africa, Spain, Sri Lanka, Sweden, Switzerland, Syria, Thailand, Togo, Trinidad and Tobago, Tunisia, Turkey, United Kingdom, United States, Uruguay, Yemen Rep., Zambia, and Zimbabwe. 


\section{References}

Acemoglu, D. "Reward Structures and the Allocation of Talent." European Economic Review, 1995, 39, 17-33.

Acemoglu, D., and T. Verdier. "The Choice Between Market Failures and Corruption." American Economic Review, 2000, 90, 194-211.

Acemoglu, D., and T. Verdier. "Property Rights, Corruption, and the Allocation of Talent: A General Equilibrium Approach." Economic Journal, 1998, 108, 1381-1403.

Adam, C.S., and D.L. Bevan. "Fiscal Deficits and Growth in Developing Countries." Journal of Public Economics, 2005, 89, 571-597.

Ahlin, C., and J. Pang. "Are Financial Development and Corruption Control Substitutes in Promoting Growth?" Journal of Development Economics, forthcoming.

Aidt, T. "Economic Analysis of Corruption: A Survey." Economic Journal, 2003, $113,632-652$.

Aidt, T., J. Dutta, and V. Sena. "Governance Regimes, Corruption and Growth: Theory and Evidence." Journal of Comparative Economics, forthcoming.

Al-Marhubi, F.A. "Corruption and Inflation." Economics Letters, 2000, 66, 199202.

Arellano, M., and S. Bond. "Some Tests of Specification for Panel Data: Monte Carlo Evidence and an Application to Employment Equations." Review of Economic Studies, 1991, 58, 277-297.

Azfar, O. "Corruption and the Delivery of Health and Education Services." Working Paper No.01/01, 2001, Centre for Institutional Reform and the Informal Sector, University of Maryland.

Bardhan, P. "Corruption and Development: A Review of the Issues." Journal of Economic Literature, 1997, 35, 1320-1346.

Basu, K., S. Bhattacharya, and A. Mishra. "Notes on Bribery and the Control of Corruption." Journal of Public Economics, 1992, 48, 349-359.

Besley, T., and J. McLaren. "Taxes and Bribery: The Role of Wage Incentives." Economic Journal, 1993, 103, 119-141.

Blackburn, K., N. Bose, and E.M. Haque. "The Incidence and Persistence of Corruption in Economic Development." Journal of Economic Dynamics and Control, 2006, 30, 2447-2467.

Blackburn, K., and G.F. Forgues-Puccio. "Distribution and Development in a Model of Misgovernance." European Economic Review, 2007, 51, 1534-1563.

Blackburn, K., and R. Sarmah. "Corruption, Development and Demography." Economics of Governance, forthcoming.

Blundel, R., and S. Bond. "Initial Conditions and Moment Restrictions in Dynamic Panel Data Models", Journal of Econometrics, 1998, 87(1), 115-143. 
Bose, G. "Bureaucratic Delays and Bribe Taking." Journal of Economic Behaviour and Organisation, 2004, 54, 313-320.

Bose, N., J.A. Holman, and K.C. Neanidis. "The Optimal Public Expenditure Financing Policy: Does the Level of Economic Development Matter?" Economic Inquiry, 2007, 45, 433-452.

Cukierman, A., S. Edwards, and G. Tabellini. "Seigniorage and Political Instability." American Economic Review, 1992, 82, 537-555.

de Haan, J., D. Zelhorst, and O. Roukens. "Seigniorage in Developing Countries." Applied Financial Economics, 1993, 3, 307-314.

Devarajan, S., V. Swaroop, and H. Zou. "The Composition of Public Expenditure and Economic Growth." Journal of Monetary Economics, 1996, 37, 313-344.

Diamond, D., and P. Dybvig. "Bank Runs, Deposit Insurance and Liquidity." Journal of Political Economy, 1983, 85, 191-206.

Dreher, A., C. Kotsogiannis, and S. McCorriston. "Corruption Around the World: Evidence from a Structural Model." Journal of Comparative Economics, 2007, 35, 443-466.

Ehrlich, I., and F.T. Lui. "Bureaucratic Corruption and Endogenous Economic Growth." Journal of Political Economy, 1999, 107, 270-293.

Espinosa-Vega, M.A., and C.K. Yip. "Fiscal and Monetary Policy Interactions in an Endogenous Growth Model with Financial Intermediaries." International Economic Review, 1999, 40, 595-615.

Espinosa-Vega, M.A., and C.K. Yip. "Government Financing in an Endogenous Growth Model with Financial Market Restrictions." Economic Theory, 2000, 20(2), 237-257.

Fischer, S. "Seigniorage and the Case for a National Money", Journal of Political Economy, 1982, 90, 295-313.

Ghura, D. "Tax Revenue in Sub-Saharan Africa: Effects of Economic Policies and Corruption." Working Paper No.135, 1998, International Monetary Fund.

Gupta, S., H. Davoodi, and E. Tiongson, E. "Corruption and the Provision of Health Care and Education Services." Working Paper No.00/116, 2000, International Monetary Fund.

Gupta, S., L. de Mello, and R. Sharan. "Corruption and Military Spending." European Journal of Political Economy, 2001, 17, 749-777.

Gyimah-Brempong, K. "Corruption, Economic Growth and Income Inequality in Africa." Economics of Governance, 2002, 3, 183-209.

Gyimah-Brempong, KA., and S.M. Camacho. "Corruption, Growth, and Income Distribution: Are There Regional Differences?" Economics of Governance, 2006, 7, 245-269. 
Hall R.E., and C. Jones. "Why Do Some Countries Produce So Much More Output per Worker than Others?" Quarterly Journal of Economics, 1999, 114, 83-116.

Hansen, L. "Large Sample Properties of Generalized Methods of Moments Estimators." Econometrica, 1982, 50, 1029-1054.

Honohan, P. "Does it Matter How Seigniorage is Measured?" Applied Financial Economics, 1996, 6, 293-300.

Huang, H., and S-J. Wei. "Monetary Policies in Developing Countries: The Role of Institutional Quality." Journal of International Economics, 2006, 70, 239-252.

Huntington, S.P. Political Order in Changing Societies. Yale University Press, 1968, New Haven, CT.

Imam, P.A., and D.F. Jacobs. "Effect of Corruption on Tax Revenues in the Middle East." Working Paper No.270, 2007, International Monetary Fund.

Jain, A.K. "Corruption: A Review." Journal of Economic Surveys, 2001, 15, 71-121.

Kaufmann, D., A. Kraay, and M. Mastruzzi. "Governance Matters V: Aggregate and Individual Governance Indicators for 1996-2005." World Bank Policy Research Working Paper 4012.

Keefer, P., and S. Knack. "Why Don't Poor Countries Catch Up? A Crossnational Test of an Institutional Explanation." Economic Inquiry, 1997, 35, 590-602.

Klitgaard, R. Controlling Corruption. University of California Press, 1988, Berkeley.

Knack, S., and P. Keefer, P. "Institutions and Economic Performance: Crosscountry Tests Using Alternative Institutional Measures." Economics and Politics, 1995, 7, 207-227.

Kneller, R., M.F. Bleaney, and N. Gemmell. "Fiscal Policy and Growth: Evidence from OECD Countries." Journal of Public Economics, 1999, 74, 171190.

Leff, N.H. "Economic Development through Bureaucratic Corruption." American Behavioural Scientist, 1964, 8, 8-14.

Li, H., L.C. Xu, and H. Zou. "Corruption, Income Distribution and Growth." Economics and Politics, 2000, 12, 155-182.

Lui, F.T. "An Equilibrium Queuing Model of Bribery." Journal of Political Economy, 1985, 93, 760-781.

Marjit, S., and H. Shi. "On Controlling Corruption with Corrupt Officials." Journal of Economic Behaviour and Organisation, 1998, 34, 163-172.

Mauro, P. "Corruption and Growth." Quarterly Journal of Economics, 1995, $110,681-712$. 
Mauro, P. "Corruption and the Composition of Government Expenditure." Journal of Public Economics, 1998, 69, 263-279.

Méndez, F., and F. Sepúlveda. "Corruption, Growth and Political Regimes: Cross Country Evidence." European Journal of Political Economy, 2006, 22, 82-98.

Miller, S., and F. Russek. "Fiscal Structures and Economic Growth: International Evidence." Economic Inquiry, 1997, 35, 603-613.

Mishra, A. "Hierarchies, Incentives and Collusion in a Model of Enforcement." Journal of Economic Behaviour and Organisation, 47, 165-178.

Montinola, G.R., and R.W. Jackman. "Sources of Corruption: A Cross-country Study." British Journal of Political Studies, 1999, 32, 147-170.

Murphy, K., A. Shleifer, and R. Vishny. "The Allocation of Talent: Implications for Growth." Quarterly Journal of Economics, 1991, 106, 503-530.

North, D.C. Institutions, Institutional Change, and Economic Performance. Cambridge University Press, 1990, Cambridge.

Paldam, M. "The Big Pattern of Corruption, Economics, Culture and Seesaw Dynamics. European Journal of Political Economy, 2002, 18, 215-240.

Pellegrini, L., and R. Gerlagh. "Corruption's Effect on Growth and its Transmission Channels." Kyklos, 2004, 57, 429-456.

Reinikka, R., and J. Svensson. "Fighting Corruption to Improve Schooling: Evidence from a Newspaper Campaign in Uganda." Journal of European Economic Association, 2005, 3, 259-267.

Roodman, D. "The Anarchy of Numbers: Aid, Development, and Cross-Country Empirics." Working Paper No.32, 2004, Center for Global Development.

Sachs, J.D., and A.M. Warner. "Sources of Slow Growth in African Economies." Journal of African Economics, 1997, 6, 335-376.

Sarte, P.D. "Informality and Rent-Seeking Bureaucracies in a Model of LongRun Growth." Journal of Monetary Economics, 2000, 46, 173-197.

Svensson, J. "Eight Questions about Corruption." Journal of Economic Perspectives, 2005, 19(3), 19-42.

Tanzi, V., and H.R. Davoodi. "Corruption, Growth, and Public Finances." Working Paper No. 182, 2000, International Monetary Fund.

Tanzi, V., and H.R. Davoodi. "Corruption, Public Investment, and Growth." Working Paper No. 139, 1997, International Monetary Fund.

Tirole, J. "A Theory of Collective Reputation (with Applications to the Persistence of Corruption and Firm Quality)." Review of Economic Studies, 1996, $63,1-22$.

Treisman, D. "The Causes of Corruption: A Cross-national Study. Journal of Public Economics, 2000, 76, 399-457. 
Walsh, C.E. Monetary Theory and Policy. MIT Press, 1998, Cambridge, MA. Wei, S. "How Taxing is Corruption on International Investors?" Review of Economics and Statistics, 2000, 82, 1-11.

World Bank. Voices of the Firms 2000: Investment Climate and Governance Findings of the World Business Environment Survey (WBES). World Bank, 2002, Washington D.C. 
Figure 1

Seigniorage and Corruption

(a) Seigniorage and ICRG

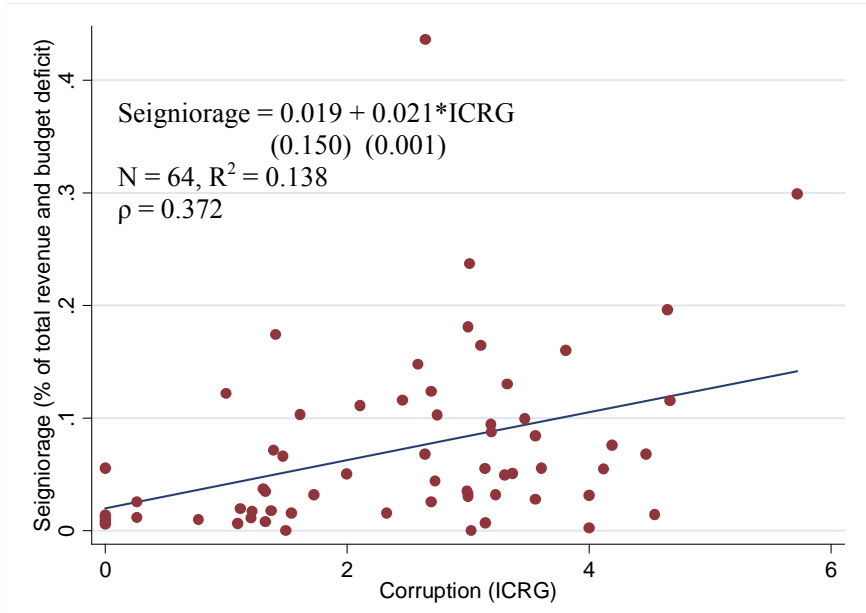

(c) Seigniorage and KKM

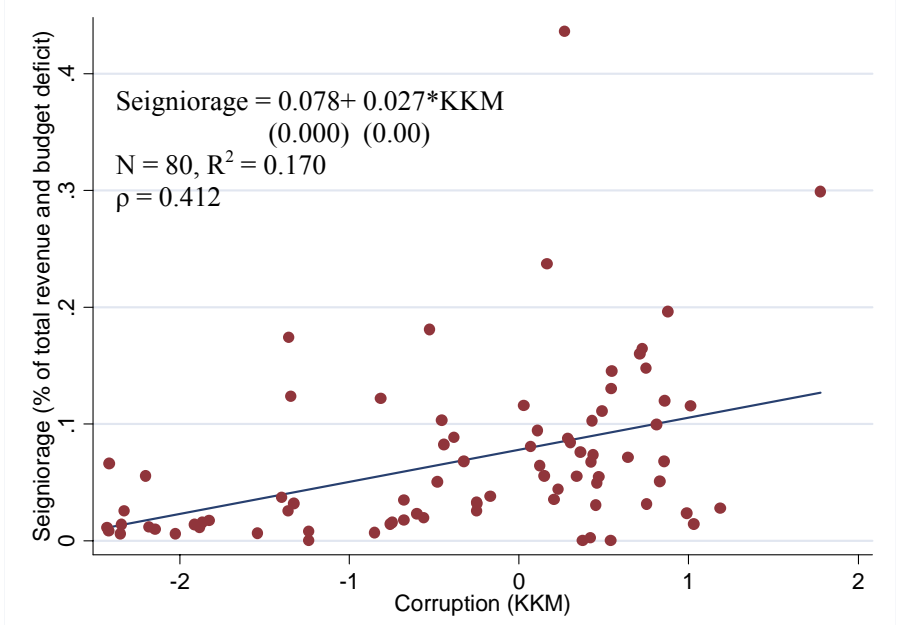

(b) Seigniorage and TI

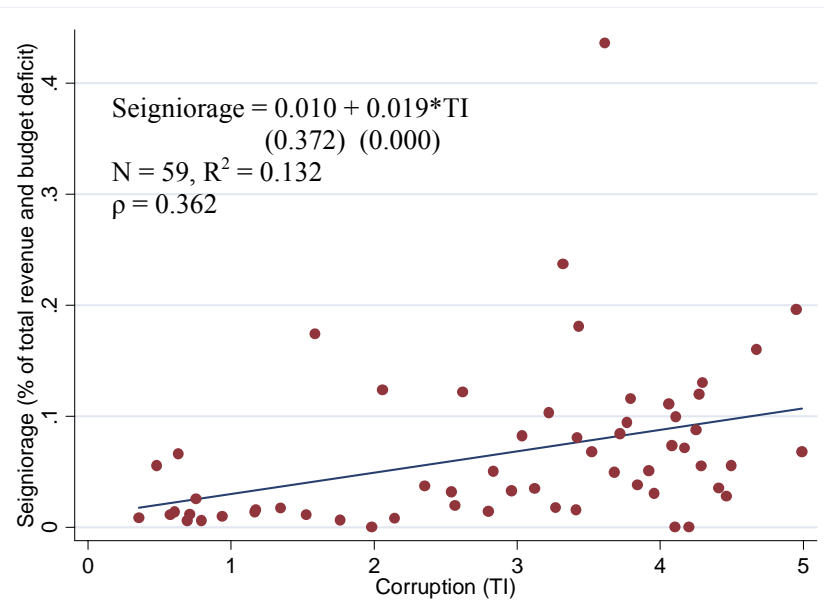

(b) Seigniorage and DKM

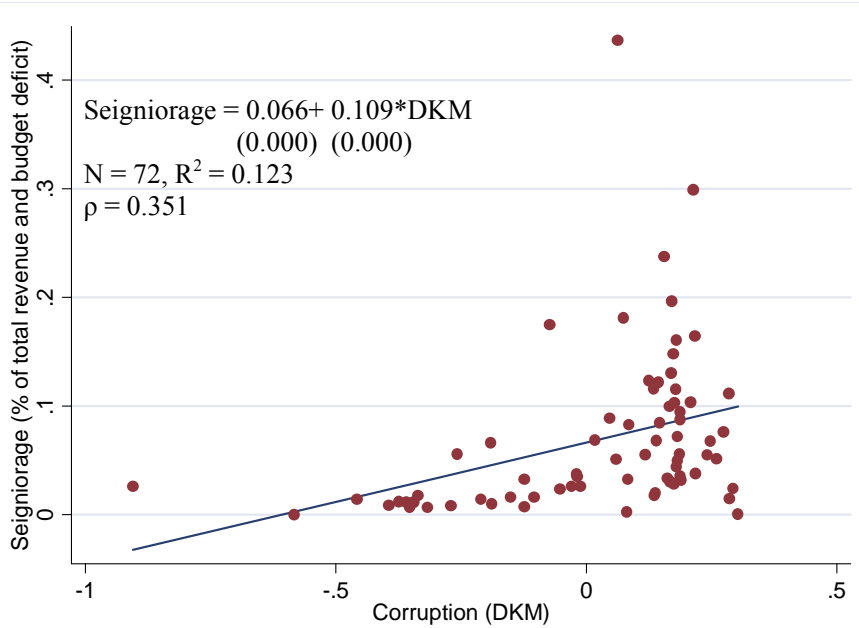

Note: Seigniorage - change in high-powered (reserve) money as a fraction of total revenue, grants, and budget deficit (average of 1970-2000); ICRG corruption, International Country Risk Guide measure (average of 1984-2000); TI - corruption, Transparency International measure (average of 1980-2000); KKM - corruption, Kaufmann et al. (2006) measure (average of 1996-2000); DKM - corruption, Dreher et al. (2007) measure (average of 1976-1997). 
Table 1

Summary statistics

\begin{tabular}{|c|c|c|c|c|c|}
\hline Variable & Mean & Std Deviation & Min & Max & Obs \\
\hline \multicolumn{6}{|l|}{ Country characteristics } \\
\hline GDP p.c. growth $(\%)$ & $1.1 \%$ & $2.9 \%$ & $-11.7 \%$ & $10.7 \%$ & 315 \\
\hline Log initial p.c. GDP (2000 US dollars) & 24.0 & 2.0 & 19.1 & 29.7 & 315 \\
\hline Investment (\% GDP) & $22.4 \%$ & $6.3 \%$ & $6.2 \%$ & $47.5 \%$ & 315 \\
\hline Population growth $(\%)$ & $1.5 \%$ & $1.7 \%$ & $-20.3 \%$ & $4.9 \%$ & 328 \\
\hline \multicolumn{6}{|l|}{ Fiscal variables (\% GDP) } \\
\hline Total revenues and grants & $28.4 \%$ & $11.3 \%$ & $6.6 \%$ & $76.5 \%$ & 280 \\
\hline Budget deficit & $3.6 \%$ & $5.7 \%$ & $-26.4 \%$ & $41.9 \%$ & 278 \\
\hline Total revenue, grants, and budget deficit & $32.0 \%$ & $12.4 \%$ & $8.5 \%$ & $90.9 \%$ & 278 \\
\hline \multicolumn{6}{|l|}{$\begin{array}{l}\text { Fiscal variables (\%Total revenue, grants, } \\
\text { and budget deficit) }\end{array}$} \\
\hline Tax revenue & $69.7 \%$ & $17.6 \%$ & $2.9 \%$ & $100.8 \%$ & 278 \\
\hline Non-tax revenue & $16.3 \%$ & $17.0 \%$ & $1.5 \%$ & $146.3 \%$ & 278 \\
\hline Grants & $3.5 \%$ & $5.8 \%$ & $0.003 \%$ & $34.4 \%$ & 223 \\
\hline Total revenue and grants & $89.2 \%$ & $14.1 \%$ & $39.3 \%$ & $161.3 \%$ & 278 \\
\hline Seigniorage & $0.3 \%$ & $0.8 \%$ & $-0.07 \%$ & $8.8 \%$ & 274 \\
\hline Debt financing & $10.5 \%$ & $14.0 \%$ & $-61.3 \%$ & $60.2 \%$ & 274 \\
\hline \multicolumn{6}{|l|}{ Corruption variables } \\
\hline ICRG & 2.4 & 1.4 & 0 & 6 & 299 \\
\hline TI & 2.6 & 1.4 & 0.2 & 5.9 & 178 \\
\hline DKM & 0.01 & 0.2 & -0.9 & 0.3 & 195 \\
\hline
\end{tabular}

Sources: Data on per capita growth, GDP per capita, investment, population growth, primary school enrollment, trade, and inflation are from the World Development Indicators (World Bank, online).

Data on fiscal variables are from the Government Finance Statistics (IMF, online), apart from data on reserve money used to calculate seigniorage, which are from the International Financial Statistics (IMF, online).

Definitions (GFS codes reported in brackets):

Tax revenue $=$ direct taxes $($ taxes on income, profits, and capital gains $[81 \mathrm{a}]+$ social security contributions $[81 \mathrm{~b}]+$ taxes on payroll $[81 \mathrm{c}]+$ taxes on property [81d]) + indirect taxes (domestic taxes on goods and services [81e]) + taxes on international trade and transactions [81f].

Non-tax revenue $=$ other taxes $[81 \mathrm{~g}]+$ non-tax revenue $[81 \mathrm{yb}]+$ capital revenue $[81 \mathrm{yc}]$.

Grants $=$ grants $[81 \mathrm{z}]$.

Total revenue and grants $=$ tax revenue + non-tax revenue + grants.

Overall budget deficit $=$ total expenditure + net lending - total revenue and grants.

Seigniorage $=$ change in reserve money as a fraction of total revenue, grants and budget deficit .

All fiscal data cover central government fiscal accounts only.

ICRG - corruption, International Country Risk Guide index

TI - corruption, Transparency International index

DKM - corruption, Dreher et al. (2007) index 
Table 2

Benchmark findings (excluded fiscal category: total revenue and grants)

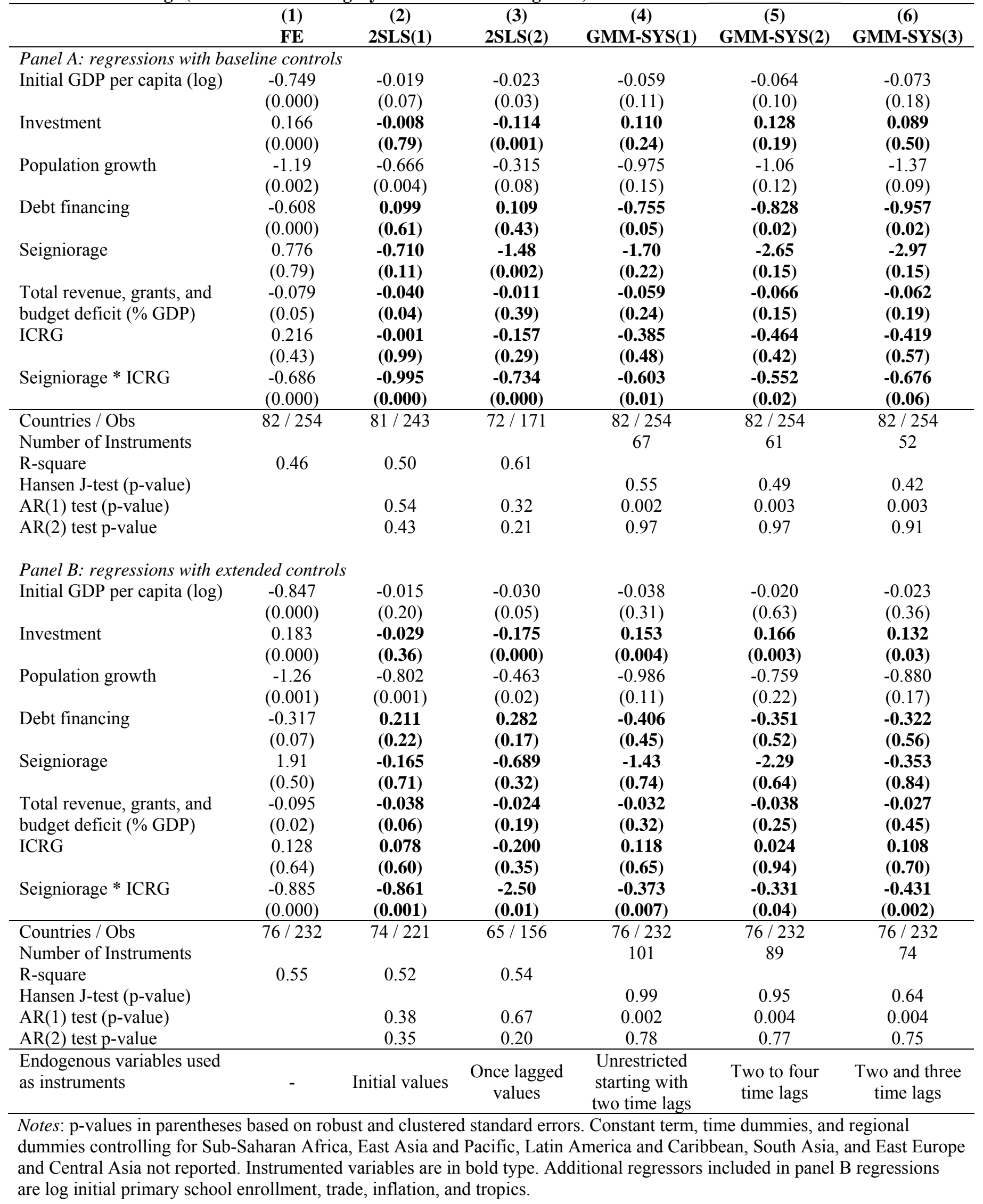


Table 3

Robustness to excluding alternative fiscal categories and to disaggregating total revenue and grants into tax revenue, non-tax revenue, and grants (excluded fiscal category: grants)

\begin{tabular}{|c|c|c|c|c|c|}
\hline & $\begin{array}{c}(1) \\
2 S L S(1) \\
\end{array}$ & $\begin{array}{c}(2) \\
\text { 2SLS(1) } \\
\end{array}$ & $\begin{array}{l}\text { (3) } \\
\text { FE }\end{array}$ & $\begin{array}{c}(4) \\
2 S L S(1)\end{array}$ & $\begin{array}{c}(5) \\
2 S L S(2)\end{array}$ \\
\hline \multicolumn{6}{|c|}{ Panel A: regressions with baseline controls } \\
\hline \multicolumn{2}{|c|}{ Debt financing } & $\begin{array}{l}0.809 \\
(0.08)\end{array}$ & $\begin{array}{l}-1.30 \\
(0.001)\end{array}$ & $\begin{array}{l}-0.446 \\
(0.30)\end{array}$ & $\begin{array}{l}0.753 \\
(0.08)\end{array}$ \\
\hline Seigniorage & $\begin{array}{l}-0.809 \\
(0.08)\end{array}$ & & $\begin{array}{l}-0.279 \\
(0.92)\end{array}$ & $\begin{array}{l}-1.21 \\
(0.09)\end{array}$ & $\begin{array}{l}-0.680 \\
(0.32)\end{array}$ \\
\hline Total revenue and grants & $\begin{array}{l}-0.099 \\
(0.61)\end{array}$ & $\begin{array}{r}0.710 \\
(0.11)\end{array}$ & & & \\
\hline Tax revenue & & & $\begin{array}{l}-0.639 \\
(0.13)\end{array}$ & $\begin{array}{l}-0.24 \\
(0.56)\end{array}$ & $\begin{array}{l}0.624 \\
(0.05)\end{array}$ \\
\hline Non-tax revenue & & & $\begin{array}{l}-0.953 \\
(0.02)\end{array}$ & $\begin{array}{l}-0.633 \\
(0.13)\end{array}$ & $\begin{array}{l}0.650 \\
(0.08)\end{array}$ \\
\hline $\begin{array}{l}\text { Total revenue, grants, and } \\
\text { budget deficit ( } \% \text { GDP) }\end{array}$ & $\begin{array}{r}-0.040 \\
(0.04)\end{array}$ & $\begin{array}{r}-0.040 \\
(0.04)\end{array}$ & $\begin{array}{l}-0.085 \\
(0.04)\end{array}$ & $\begin{array}{l}-0.025 \\
(0.09)\end{array}$ & $\begin{array}{l}-0.011 \\
(0.43)\end{array}$ \\
\hline ICRG & $\begin{array}{l}-0.001 \\
(0.99)\end{array}$ & $\begin{array}{l}-0.001 \\
(0.99)\end{array}$ & $\begin{array}{l}0.265 \\
(0.33)\end{array}$ & $\begin{array}{l}0.118 \\
(0.32)\end{array}$ & $\begin{array}{l}-0.129 \\
(0.38)\end{array}$ \\
\hline Seigniorage * ICRG & $\begin{array}{l}-0.995 \\
(0.000)\end{array}$ & $\begin{array}{c}-0.995 \\
(0.000)\end{array}$ & $\begin{array}{c}-0.764 \\
(0.000)\end{array}$ & $\begin{array}{l}-1.20 \\
(0.000)\end{array}$ & $\begin{array}{c}-0.733 \\
(0.000)\end{array}$ \\
\hline Countries / Obs & $81 / 243$ & $81 / 243$ & $82 / 254$ & $81 / 242$ & $72 / 171$ \\
\hline R-square & 0.50 & 0.50 & 0.47 & 0.51 & 0.62 \\
\hline $\operatorname{AR}(1)$ test (p-value) & 0.54 & 0.54 & & 0.57 & 0.36 \\
\hline $\mathrm{AR}(2)$ test $\mathrm{p}$-value & 0.43 & 0.43 & & 0.28 & 0.19 \\
\hline \multicolumn{6}{|c|}{ Panel B: regressions with extended controls } \\
\hline \multicolumn{2}{|c|}{ Debt financing } & $\begin{array}{l}0.377 \\
(\mathbf{0 . 3 8})\end{array}$ & $\begin{array}{c}-1.23 \\
(0.002)\end{array}$ & $\begin{array}{l}-0.548 \\
(0.28)\end{array}$ & $\begin{array}{c}1.00 \\
(0.07)\end{array}$ \\
\hline Seigniorage & $\begin{array}{l}-0.377 \\
(0.38)\end{array}$ & & $\begin{array}{l}-0.642 \\
(0.81)\end{array}$ & $\begin{array}{l}-0.871 \\
(0.29)\end{array}$ & $\begin{array}{l}0.465 \\
(0.56)\end{array}$ \\
\hline Total revenue and grants & $\begin{array}{l}-0.211 \\
(0.22)\end{array}$ & $\begin{array}{l}0.165 \\
(0.71)\end{array}$ & & & \\
\hline Tax revenue & & & $\begin{array}{l}-0.319 \\
(0.45)\end{array}$ & $\begin{array}{c}-0.419 \\
(0.39\end{array}$ & $\begin{array}{l}0.711 \\
(0.11)\end{array}$ \\
\hline Non-tax revenue & & & $\begin{array}{c}-1.64 \\
(0.000)\end{array}$ & $\begin{array}{l}-0.871 \\
(0.07)\end{array}$ & $\begin{array}{l}0.737 \\
(\mathbf{0 . 1 6})\end{array}$ \\
\hline $\begin{array}{l}\text { Total revenue, grants, and } \\
\text { budget deficit ( } \% \text { GDP) }\end{array}$ & $\begin{array}{l}-0.038 \\
(0.06)\end{array}$ & $\begin{array}{l}-0.038 \\
(0.06)\end{array}$ & $\begin{array}{l}-0.054 \\
(0.19)\end{array}$ & $\begin{array}{l}-0.027 \\
(0.14)\end{array}$ & $\begin{array}{l}-0.014 \\
(0.42)\end{array}$ \\
\hline ICRG & $\begin{array}{c}0.078 \\
(0.060)\end{array}$ & $\begin{array}{c}0.078 \\
(0.060)\end{array}$ & $\begin{array}{l}-0.005 \\
(0.98)\end{array}$ & $\begin{array}{l}0.229 \\
(0.10)\end{array}$ & $\begin{array}{l}0.084 \\
(0.65)\end{array}$ \\
\hline Seigniorage * ICRG & $\begin{array}{l}-0.861 \\
(0.001) \\
\end{array}$ & $\begin{array}{l}-0.861 \\
(0.001) \\
\end{array}$ & $\begin{array}{l}-0.850 \\
(0.000) \\
\end{array}$ & $\begin{array}{c}-1.22 \\
(0.000)\end{array}$ & $\begin{array}{c}-1.04 \\
(0.003) \\
\end{array}$ \\
\hline Countries / Obs & $74 / 221$ & $74 / 221$ & $75 / 230$ & $74 / 220$ & $65 / 157$ \\
\hline R-square & 0.52 & 0.52 & 0.59 & 0.53 & 0.63 \\
\hline AR(1) test (p-value) & 0.38 & 0.38 & & 0.22 & 0.30 \\
\hline $\mathrm{AR}(2)$ test $\mathrm{p}$-value & 0.35 & 0.35 & & 0.38 & 0.18 \\
\hline $\begin{array}{l}\text { Endogenous variables used } \\
\text { as instruments }\end{array}$ & Initial values & Initial values & - & Initial values & $\begin{array}{l}\text { Once laggec } \\
\text { values }\end{array}$ \\
\hline
\end{tabular}

Regression (1) involves the specification of Table 2 but instead excludes debt financing.

Regression (2) involves the specification of Table 2 but instead excludes seigniorage.

Regressions (3) to (5) involve the disaggregation of total revenue and grants, and exclude grants.

Notes: p-values in parentheses based on robust and clustered standard errors. Constant term, time dummies, and regional dummies controlling for Sub-Saharan Africa, East Asia and Pacific, Latin America and Caribbean, South Asia, and East Europe and Central Asia not reported. Instrumented variables are in bold type. Regressors included in Panel A are log initial GDP per capita, investment, and population growth. Additional regressors included in panel B regressions are log initial primary school enrollment, trade, inflation, and tropics. 
Table 4

Robustness to excluding from the sample one country at a time (excluded fiscal category: total revenue and grants)

\begin{tabular}{|c|c|c|c|}
\hline & $\begin{array}{l}\text { (1) } \\
\text { FE }\end{array}$ & $\begin{array}{c}(2) \\
2 S L S(1)\end{array}$ & $\begin{array}{c}(3) \\
2 S L S(2)\end{array}$ \\
\hline \multicolumn{4}{|c|}{ Panel A: regressions with baseline controls } \\
\hline Seigniorage * ICRG & -0.686 & -0.995 & -0.734 \\
\hline (p-value) & $(0.000)$ & $(0.000)$ & $(0.000)$ \\
\hline [t-statistic] & {$[-4.11]$} & {$[-3.72]$} & {$[-3.91]$} \\
\hline Seigniorage * ICRG (MIN) & -0.665 & -0.821 & -0.640 \\
\hline (p-value) & $(0.000)$ & $(0.000)$ & $(0.000)$ \\
\hline [t-statistic] & {$[-3.98]$} & {$[-4.42]$} & {$[-4.94]$} \\
\hline Seigniorage * ICRG (MAX) & -0.711 & -1.39 & -0.802 \\
\hline (p-value) & $(0.000)$ & $(0.003)$ & $(0.000)$ \\
\hline [t-statistic $]$ & {$[-4.39]$} & {$[-2.97]$} & {$[-3.76]$} \\
\hline \multicolumn{4}{|c|}{ Panel B: regressions with extended controls } \\
\hline Seigniorage * ICRG & -0.885 & -0.861 & -2.50 \\
\hline (p-value) & $(0.000)$ & $(0.001)$ & $(0.01)$ \\
\hline [t-statistic] & {$[-5.36]$} & {$[-3.28]$} & {$[-2.37]$} \\
\hline Seigniorage * ICRG (MIN) & -0.827 & -0.736 & -1.72 \\
\hline (p-value) & $(0.000)$ & $(0.012)$ & $(0.000)$ \\
\hline$[\mathrm{t}$-statistic $]$ & {$[-5.25]$} & {$[-2.50]$} & {$[-3.64]$} \\
\hline Seigniorage * ICRG (MAX) & -0.906 & -1.35 & -3.36 \\
\hline (p-value) & $(0.000)$ & $(0.000)$ & $(0.022)$ \\
\hline [t-statistic] & {$[-5.55]$} & {$[-5.54]$} & [2.29] \\
\hline $\begin{array}{l}\text { Endogenous variables used } \\
\text { as instruments }\end{array}$ & - & Initial values & $\begin{array}{l}\text { Once lagged } \\
\text { values }\end{array}$ \\
\hline \multicolumn{4}{|c|}{$\begin{array}{l}\text { Notes: The table reports coefficients and p-values (in parentheses based on } \\
\text { robust and clustered standard errors) for the seigniorage and corruption } \\
\text { interaction term. Panels A and B follow the specifications of panels A and B } \\
\text { of Table } 2 \text {. The coefficients of Table } 2 \text { are reproduced here, along with the } \\
\text { minimum and maximum coefficients of the interaction term and their t- } \\
\text { statistics (in brackets) that result from dropping one country at a time from the } \\
\text { sample. Instrumented variables are in bold type. }\end{array}$} \\
\hline
\end{tabular}


Table 6

Robustness to alternative measures of seigniorage (excluded fiscal category: total revenue and grants)

\begin{tabular}{|c|c|c|c|c|c|c|}
\hline & $\begin{array}{c}(1) \\
2 S L S(1)\end{array}$ & $\begin{array}{c}(2) \\
\text { GMM-SYS(1) }\end{array}$ & $\begin{array}{c}(3) \\
2 S L S(1) \\
\end{array}$ & $\begin{array}{c}\text { (4) } \\
\text { GMM-SYS(1) }\end{array}$ & $\begin{array}{c}(5) \\
2 S L S(1) \\
\end{array}$ & $\begin{array}{c}(6) \\
\text { GMM-SYS(1) }\end{array}$ \\
\hline Debt financing & $\begin{array}{r}0.102 \\
(0.60)\end{array}$ & $\begin{array}{c}-1.09 \\
(0.01)\end{array}$ & $\begin{array}{l}0.092 \\
(0.63)\end{array}$ & $\begin{array}{c}-0.733 \\
(0.08)\end{array}$ & $\begin{array}{l}0.134 \\
(0.45)\end{array}$ & $\begin{array}{l}-0.741 \\
(0.10)\end{array}$ \\
\hline Seigniorage & $\begin{array}{c}-3.31 \\
(0.000)\end{array}$ & $\begin{array}{l}-0.775 \\
(0.02)\end{array}$ & $\begin{array}{l}-1.72 \\
(0.08)\end{array}$ & $\begin{array}{l}-4.56 \\
(0.22)\end{array}$ & $\begin{array}{l}-0.538 \\
(0.37)\end{array}$ & $\begin{array}{l}-4.35 \\
(0.03)\end{array}$ \\
\hline $\begin{array}{l}\text { Total revenue, grants, } \\
\text { and budget deficit ( } \% \\
\text { GDP) }\end{array}$ & $\begin{array}{l}-0.041 \\
(0.04)\end{array}$ & $\begin{array}{l}-0.086 \\
(0.10)\end{array}$ & $\begin{array}{l}-0.039 \\
(0.05)\end{array}$ & $\begin{array}{l}-0.086 \\
(0.11)\end{array}$ & $\begin{array}{l}-0.028 \\
(0.11)\end{array}$ & $\begin{array}{l}-0.076 \\
(0.15)\end{array}$ \\
\hline ICRG & $\begin{array}{l}0.007 \\
(0.96)\end{array}$ & $\begin{array}{l}-0.322 \\
(0.52)\end{array}$ & $\begin{array}{l}-0.026 \\
(0.85)\end{array}$ & $\begin{array}{l}-0.338 \\
(0.55)\end{array}$ & $\begin{array}{l}0.002 \\
(0.98)\end{array}$ & $\begin{array}{l}-0.647 \\
(0.26)\end{array}$ \\
\hline Seigniorage * ICRG & $\begin{array}{c}-1.70 \\
(0.001)\end{array}$ & $\begin{array}{l}-\mathbf{0 . 6 8 8} \\
(\mathbf{0 . 0 1})\end{array}$ & $\begin{array}{r}-\mathbf{0 . 8 3 7} \\
(\mathbf{0 . 0 1})\end{array}$ & $\begin{array}{l}-\mathbf{0 . 3 7 7} \\
(\mathbf{0 . 0 2})\end{array}$ & $\begin{array}{c}-1.31 \\
(0.001)\end{array}$ & $\begin{array}{l}-0.768 \\
(0.04)\end{array}$ \\
\hline $\begin{array}{l}\text { Countries / Obs } \\
\text { Number of Instruments }\end{array}$ & $81 / 242$ & $\begin{array}{c}82 / 254 \\
67\end{array}$ & $81 / 243$ & $\begin{array}{c}82 / 254 \\
67\end{array}$ & $78 / 237$ & $\begin{array}{c}80 / 248 \\
67\end{array}$ \\
\hline R-square & 0.47 & & 0.50 & & 0.53 & \\
\hline Hansen J-test ( $p$-value) & & 0.31 & & 0.55 & & 0.68 \\
\hline $\mathrm{AR}(1)$ test (p-value) & 0.15 & 0.006 & 0.48 & 0.003 & 0.51 & 0.004 \\
\hline $\mathrm{AR}(2)$ test $\mathrm{p}$-value & 0.84 & 0.62 & 0.44 & 0.95 & 0.06 & 0.83 \\
\hline $\begin{array}{l}\text { Endogenous variables } \\
\text { used as instruments }\end{array}$ & Initial values & $\begin{array}{l}\text { Unrestricted } \\
\text { starting with two } \\
\text { time lags }\end{array}$ & Initial values & $\begin{array}{l}\text { Unrestricted } \\
\text { starting with two } \\
\text { time lags }\end{array}$ & Initial values & $\begin{array}{l}\text { Unrestricted } \\
\text { starting with } \\
\text { two time lags }\end{array}$ \\
\hline
\end{tabular}

Regressions (1) and (2) involve seigniorage measured by Seigniorage 2.

Regressions (3) and (4) involve seigniorage measured by Seigniorage3.

Regressions (5) and (6) involve seigniorage measured by Seigniorage4.

Notes: p-values in parentheses based on robust and clustered standard errors. Constant term, time dummies, and regional dummies controlling for Sub-Saharan Africa, East Asia and Pacific, Latin America and Caribbean, South Asia, and East Europe and Central Asia not reported. Instrumented variables are in bold type. Additional regressors included are log initial GDP per capita, investment, and population growth. 
Table 7

Robustness to nonlinear, convergence, and other proposed interaction effects (excluded fiscal category: total revenue and grants)

\begin{tabular}{|c|c|c|c|c|c|c|c|}
\hline & $\begin{array}{c}(1) \\
2 S L S(1)\end{array}$ & $\begin{array}{c}(2) \\
2 S L S(1)\end{array}$ & $\begin{array}{c}(3) \\
2 S L S(1)\end{array}$ & $\begin{array}{c}\text { (4) } \\
2 S L S(1)\end{array}$ & $\begin{array}{c}(5) \\
2 S L S(1)\end{array}$ & $\begin{array}{c}(6) \\
2 S L S(1)\end{array}$ & $\begin{array}{c}(7) \\
2 S L S(1)\end{array}$ \\
\hline Debt financing & $\begin{array}{l}0.086 \\
(0.67)\end{array}$ & $\begin{array}{l}0.097 \\
(0.62)\end{array}$ & $\begin{array}{l}0.096 \\
(0.62)\end{array}$ & $\begin{array}{l}0.089 \\
(0.65)\end{array}$ & $\begin{array}{l}0.159 \\
(0.37)\end{array}$ & $\begin{array}{l}0.160 \\
(0.40)\end{array}$ & $\begin{array}{l}0.076 \\
(0.71)\end{array}$ \\
\hline Seigniorage & $\begin{array}{l}-0.679 \\
(0.15)\end{array}$ & $\begin{array}{c}2.06 \\
(0.36)\end{array}$ & $\begin{array}{c}-0.682 \\
(0.11)\end{array}$ & $\begin{array}{c}2.28 \\
(0.18)\end{array}$ & $\begin{array}{c}-0.916 \\
(0.07)\end{array}$ & $\begin{array}{l}-0.539 \\
(0.24)\end{array}$ & $\begin{array}{c}-0.648 \\
(0.15)\end{array}$ \\
\hline $\begin{array}{l}\text { Total revenue, grants, } \\
\text { and budget deficit ( } \% \\
\text { GDP) }\end{array}$ & $\begin{array}{l}-0.039 \\
(0.05)\end{array}$ & $\begin{array}{r}-0.041 \\
(0.04)\end{array}$ & $\begin{array}{c}-0.035 \\
(0.07)\end{array}$ & $\begin{array}{r}-0.041 \\
(0.04)\end{array}$ & $\begin{array}{c}-0.028 \\
(0.09)\end{array}$ & $\begin{array}{c}-0.021 \\
(0.26)\end{array}$ & $\begin{array}{c}-0.039 \\
(0.05)\end{array}$ \\
\hline ICRG & $\begin{array}{l}0.166 \\
(0.56)\end{array}$ & $\begin{array}{l}0.008 \\
(0.95)\end{array}$ & $\begin{array}{l}-0.301 \\
(0.02)\end{array}$ & $\begin{array}{l}0.049 \\
(0.73)\end{array}$ & $\begin{array}{l}-0.201 \\
(0.32)\end{array}$ & $\begin{array}{l}0.343 \\
(0.38)\end{array}$ & $\begin{array}{l}0.140 \\
(0.54)\end{array}$ \\
\hline Seigniorage * ICRG & $\begin{array}{c}-0.942 \\
(0.001)\end{array}$ & $\begin{array}{c}-1.04 \\
(0.000)\end{array}$ & $\begin{array}{c}-0.899 \\
(0.000)\end{array}$ & $\begin{array}{c}-1.34 \\
(0.001)\end{array}$ & $\begin{array}{l}-1.81 \\
(0.05)\end{array}$ & $\begin{array}{c}-1.03 \\
(0.001)\end{array}$ & $\begin{array}{c}-0.886 \\
(0.000)\end{array}$ \\
\hline $\mathrm{ICRG}^{2}$ & $\begin{array}{c}-0.036 \\
(0.52)\end{array}$ & & & & & & \\
\hline Seigniorage $^{2}$ & & $\begin{array}{l}-0.033 \\
(0.18)\end{array}$ & & & & & \\
\hline $\begin{array}{l}\text { ICRG * Log initial pc } \\
\text { GDP }\end{array}$ & & & $\begin{array}{c}-0.042 \\
(0.003)\end{array}$ & & & & \\
\hline $\begin{array}{l}\text { Seigniorage } * \text { Log } \\
\text { initial pc GDP }\end{array}$ & & & & $\begin{array}{r}-0.910 \\
(0.17)\end{array}$ & & & \\
\hline Financial development & & & & & $\begin{array}{l}-0.853 \\
(0.16)\end{array}$ & & \\
\hline $\begin{array}{l}\text { ICRG * Financial } \\
\text { development }\end{array}$ & & & & & $\begin{array}{l}0.061 \\
(0.07)\end{array}$ & & \\
\hline $\begin{array}{l}\text { Government } \\
\text { expenditures } \\
\text { ICRG * Government } \\
\text { expenditures }\end{array}$ & & & & & & $\begin{array}{l}-0.005 \\
(0.92) \\
-0.003 \\
(0.20)\end{array}$ & \\
\hline $\mathrm{ICRG} * \mathrm{SSA}$ & & & & & & & $\begin{array}{c}-0.288 \\
(0.29)\end{array}$ \\
\hline $\mathrm{ICRG} * \mathrm{EAP}$ & & & & & & & $\begin{array}{l}0.193 \\
(0.61)\end{array}$ \\
\hline $\mathrm{ICRG} * \mathrm{LAC}$ & & & & & & & $\begin{array}{l}-0.610 \\
(0.05)\end{array}$ \\
\hline $\mathrm{ICRG} * \mathrm{SA}$ & & & & & & & $\begin{array}{l}-0.036 \\
(0.95)\end{array}$ \\
\hline $\mathrm{ICRG} * \mathrm{ECA}$ & & & & & & & $\begin{array}{r}0.180 \\
(0.82) \\
\end{array}$ \\
\hline Countries / Obs & $78 / 236$ & $81 / 243$ & $81 / 243$ & $81 / 243$ & $76 / 205$ & $81 / 240$ & $81 / 243$ \\
\hline R-square & 0.50 & 0.49 & 0.51 & 0.46 & 0.56 & 0.51 & 0.52 \\
\hline AR(1) test (p-value) & 0.62 & 0.59 & 0.54 & 0.96 & 0.15 & 0.48 & 0.53 \\
\hline AR(2) test p-value & 0.45 & 0.45 & 0.26 & 0.56 & 0.29 & 0.52 & 0.22 \\
\hline
\end{tabular}

Endogenous variables $\quad$ Initial values $\quad$ Initial values $\quad$ Initial values $\quad$ Initial values Initial values Initial values Initial values
used as instruments

Notes: p-values in parentheses based on robust and clustered standard errors. Constant term, time dummies, and regional dummies controlling for Sub-Saharan Africa (SSA), East Asia and Pacific (ECA), Latin America and Caribbean (LAC), South Asia (SA), and East Europe and Central Asia (ECA) not reported. Instrumented variables are in bold type. Additional regressors included are log initial GDP per capita, investment, and population growth. 


\section{CESifo Working Paper Series}

for full list see www.cesifo-group.org/wp

(address: Poschingerstr. 5, 81679 Munich, Germany, office@cesifo.de)

2289 Mikael Priks, Do Surveillance Cameras Affect Unruly Behavior? A Close Look at Grandstands, April 2008

2290 Marianna Belloc and Daniela Federici, A Two-Country NATREX Model for the Euro/Dollar, April 2008

2291 Nicolas Treich, The Value of a Statistical Life under Ambiguity Aversion, April 2008

2292 J. Atsu Amegashie, Socially-Tolerable Discrimination, April 2008

2293 M. Hashem Pesaran and Andreas Pick, Forecasting Random Walks Under Drift Instability, April 2008

2294 Steven Brakman, Gus Garita, Harry Garretsen and Charles van Marrewijk, Unlocking the Value of Cross-Border Mergers and Acquisitions, May 2008

2295 Eric O’N. Fisher and Kathryn G. Marshall, The Structure of the American Economy, May 2008

2296 Claudia M. Buch and Martin Schlotter, Regional Origins of Employment Volatility: Evidence from German States, May 2008

2297 Helmuth Cremer, Philippe De Donder, Dario Maldonado and Pierre Pestieau, Taxing Sin Goods and Subsidizing Health Care, May 2008

2298 Reinhilde Veugelers and Frederick van der Ploeg, Reforming European Universities: Scope for an Evidence-Based Process, May 2008

2299 Jon H. Fiva and Lars J. Kirkebøen, Does the Housing Market React to New Information on School Quality?, May 2008

2300 Tina Klautke and Alfons J. Weichenrieder, Interest Income Tax Evasion, the EU Savings Directive, and Capital Market Effects, May 2008

2301 Harald Badinger and Peter Egger, GM Estimation of Higher Order Spatial Autoregressive Processes in Panel Data Error Component Models, May 2008

2302 Jan K. Brueckner, Slot-Based Approaches to Airport Congestion Management, May 2008

2303 Sören Blomquist, Vidar Christiansen and Luca Micheletto, Public Provision of Private Goods and Nondistortionary Marginal Tax Rates, May 2008

2304 Dan Anderberg and Alessandro Balestrino, The Political Economy of Post-Compulsory Education Policy with Endogenous Credit Constraints, May 2008 
2305 Tomer Blumkin, Yoram Margalioth and Efraim Sadka, The Role of Stigma in the Design of Welfare Programs, May 2008

2306 Vesa Kanniainen and Paolo M. Panteghini, Tax Neutrality: Illusion or Reality? The Case of Entrepreneurship, May 2008

2307 Thomas Dohmen, Armin Falk, David Huffman and Uwe Sunde, The Intergenerational Transmission of Risk and Trust Attitudes, May 2008

2308 Guglielmo Maria Caporale and Mario Cerrato, Using Chebyshev Polynomials to Approximate Partial Differential Equations, May 2008

2309 Peter Egger and Doina Maria Radulescu, Labour Taxation and Foreign Direct Investment, May 2008

2310 Laurent Linnemer, Dissipative Advertising Signals Quality even without Repeat Purchases, May 2008

2311 Jordi Jofre-Monseny and Albert Solé-Ollé, Which Communities should be afraid of Mobility? The Effects of Agglomeration Economies on the Sensitivity of Firm Location to Local Taxes, May 2008

2312 Andreas Haufler and Ferdinand Mittermaier, Unionisation Triggers Tax Incentives to Attract Foreign Direct Investment, May 2008

2313 Ronel Elul and Piero Gottardi, Bankruptcy: Is it enough to Forgive or must we also Forget?, May 2008

2314 Andreas Irmen and Johanna Kuehnel, Productive Government Expenditure and Economic Growth, May 2008

2315 Beate Henschel, Carsten Pohl and Marcel Thum, Demographic Change and Regional Labour Markets: The Case of Eastern Germany, May 2008

2316 Gabriel Felbermayr, Wido Geis and Wilhelm Kohler, Restrictive Immigration Policy in Germany: Pains and Gains Foregone?, May 2008

2317 Michael Hofmann, Gerhard Kempkes and Helmut Seitz, Demographic Change and Public Sector Budgets in a Federal System, May 2008

2318 Paul De Grauwe, Macroeconomic Modeling when Agents are Imperfectly Informed, June 2008

2319 Johann K. Brunner and Susanne Pech, Optimum Taxation of Inheritances, June 2008

2320 Thomas Eichner and Marco Runkel, Corporate Income Taxation of Multinationals in a General Equilibrium Model, June 2008

2321 Rainald Borck and Matthias Wrede, Subsidies for Intracity and Intercity Commuting, June 2008 
2322 Patricia Apps and Ray Rees, Testing the Pareto Efficiency of Household Resource Allocations, June 2008

2323 Amihai Glazer, Vesa Kanniainen and Panu Poutvaara, Firms' Ethics, Consumer Boycotts, and Signalling, June 2008

2324 Claudia M. Buch, Jörg Döpke and Kerstin Stahn, Great Moderation at the Firm Level? Unconditional vs. Conditional Output Volatility, June 2008

2325 Helmuth Cremer, Philippe De Donder, Dario Maldonado and Pierre Pestieau, Forced Saving, Redistribution and Nonlinear Social Security Schemes, June 2008

2326 M. Hashem Pesaran and Paolo Zaffaroni, Optimal Asset Allocation with Factor Models for Large Portfolios, June 2008

2327 Harald Badinger and Peter Egger, Horizontal versus Vertical Interdependence in Multinational Activity, June 2008

2328 Jan K. Brueckner and Harris Selod, A Theory of Urban Squatting and Land-Tenure Formalization in Developing Countries, June 2008

2329 Paolo M. Panteghini, Corporate Debt, Hybrid Securities and the Effective Tax Rate, June 2008

2330 Guglielmo Maria Caporale, Juncal Cuñado and Luis A. Gil-Alana, Modelling Long-Run Trends and Cycles in Financial Time Series Data, June 2008

2331 Avi Ben-Bassat and Momi Dahan, Social Identity and Voter Turnout, June 2008

2332 Martin R. West and Ludger Wößmann, "Every Catholic Child in a Catholic School”: Historical Resistance to State Schooling, Contemporary Private Competition, and Student Achievement across Countries, June 2008

2333 Erkki Koskela and Panu Poutvaara, Outsourcing and Labor Taxation in Dual Labor Markets, June 2008

2334 Philippe Choné and Laurent Linnemer, Optimal Litigation Strategies with Signaling and Screening, June 2008

2335 Albert Solé-Ollé and Pilar Sorribas-Navarro, Does Partisan Alignment Affect the Electoral Reward of Intergovernmental Transfers?, June 2008

2336 Antonio Cabrales and Piero Gottardi, Markets for Information: Of Inefficient Firewalls and Efficient Monopolies, June 2008

2337 Sumon Majumdar and Sharun W. Mukand, The Leader as Catalyst - on Leadership and the Mechanics of Institutional Change, June 2008

2338 Ulrich Hange, Tax Competition, Elastic Labor Supply, and Growth, June 2008 
2339 Guy Laroque and Bernard Salanié, Does Fertility Respond to Financial Incentives?, June 2008

2340 Adriano Paggiaro, Enrico Rettore and Ugo Trivellato, The Effect of Extending the Duration of Eligibility in an Italian Labour Market Programme for Dismissed Workers, June 2008

2341 Helmut Seitz, Minimum Standards, Fixed Costs and Taxing Autonomy of Subnational Governments, June 2008

2342 Robert S. Chirinko, Leo de Haan and Elmer Sterken, Asset Price Shocks, Real Expenditures, and Financial Structure: A Multi-Country Analysis, July 2008

2343 Wolfgang Leininger, Evolutionarily Stable Preferences in Contests, July 2008

2344 Hartmut Egger and Udo Kreickemeier, Fairness, Trade, and Inequality, July 2008

2345 Ngo Van Long and Bodhisattva Sengupta, Yardstick Competition, Corruption, and Electoral Incentives, July 2008

2346 Florian Baumann, Employment Protection: The Case of Limited Enforceability, July 2008

2347 Alessandro Balestrino, Cinzia Ciardi and Claudio Mammini, On the Causes and Consequences of Divorce, July 2008

2348 Dirk Schindler and Benjamin Weigert, Insuring Educational Risk: Opportunities versus Income, July 2008

2349 Lammertjan Dam and Ben J. Heijdra, The Environmental and Macroeconomic Effects of Socially Responsible Investment, July 2008

2350 Avner Greif, Contract Enforcement and Institutions among the Maghribi Traders: Refuting Edwards and Ogilvie, July 2008

2351 Helmuth Cremer, Philippe De Donder, Dario Maldonado and Pierre Pestieau, Habit Formation and Labor Supply, July 2008

2352 Francesco Menoncin and Paolo M. Panteghini, The Johansson-Samuelson Theorem in General Equilibrium: A Rebuttal, July 2008

2353 Michael Kaganovich and Itzhak Zilcha, Alternative Social Security Systems and Growth, July 2008

2354 Keith Blackburn, Kyriakos C. Neanidis and M. Emranul Haque, Corruption, Seigniorage and Growth: Theory and Evidence, July 2008 